TOLERANCE TESTING FOR COOKED PORRIDGE MADE FROM A SORGHUM BASED FORTIFIED BLENDED FOOD

by

\title{
SIRICHAT CHANADANG
}

B.S., Chiang Mai University, 2009

\begin{abstract}
A THESIS
submitted in partial fulfillment of the requirements for the degree
\end{abstract}

MASTER OF SCIENCE

Department of Human Nutrition

College of Human Ecology

\section{KANSAS STATE UNIVERSITY \\ Manhattan, Kansas}

2015

Approved by:

Major Professor

Dr. Kadri Koppel 


\begin{abstract}
Products must be tolerant to many conditions, particularly when those products are prepared by consumers. Consumers may not measure added ingredients, they may add or leave out ingredients specified in recipes, or change cooking and holding times for foods. Fortified blended food (FBFs) are used as a source of nutrition for disaster or famine relief in developing countries and sorghum is looked at as a potential alternative to wheat and corn based products that are currently being used as FBFs. Porridge products are the most common dishes prepared from FBFs with a wide range of solids content, cooking times and variations in added ingredients such as sugar and fruit. This study was intended to evaluate the tolerance to preparation variations for a porridge product made as a FBF intended for food aid. Whole Sorghum Soy Blend (WSSB), a fortified, extruded, ground cooked cereal was selected as the FBF for this study. Descriptive sensory analysis was performed to evaluate the tolerance of porridge products made from variations in ingredients and cooking procedures. In this study, most sensory properties were only marginally affected by variations in ingredients or procedures. However, as expected, large differences occurred in some properties such as thickness when solids content varied or sweetness and fruit flavor when fruit was added. Tolerance testing showed that the sensory properties of WSSB had high tolerance to variations in cooking procedures, a positive aspect for product use and development. This means that the product can be modified during preparation by consumers without having a major impact on most sensory properties.
\end{abstract}




\section{Table of Contents}

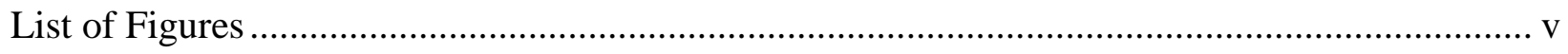

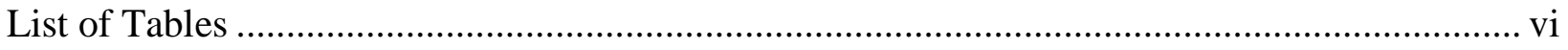

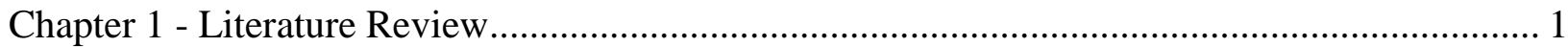

Consumer behavior related to food preparation ............................................................... 1

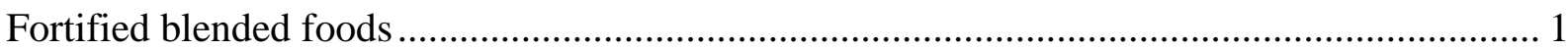

History of Fortified blended foods ............................................................................... 2

Advantages of Fortified blended foods .................................................................. 3

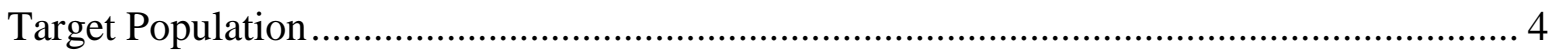

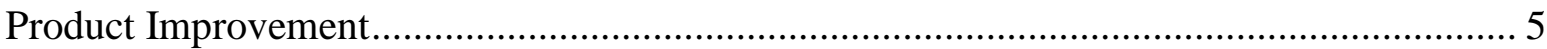

Recommendations for product changes ............................................................... 7

Newly developed fortified blended foods ............................................................... 10

Preparation and use of fortified blended foods ......................................................... 13

Sensory evaluation of fortified blended foods ........................................................ 16

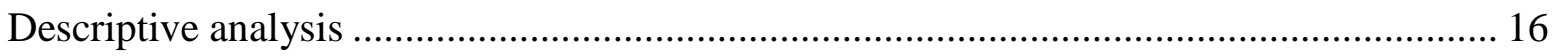

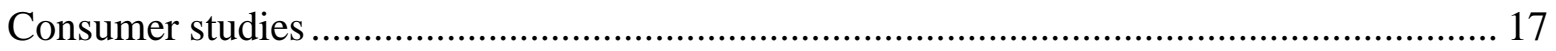

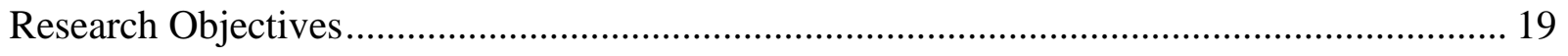

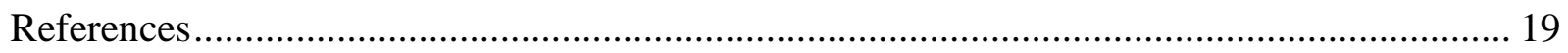

Chapter 2 - Tolerance testing for cooked porridge made from a sorghum based fortified blended

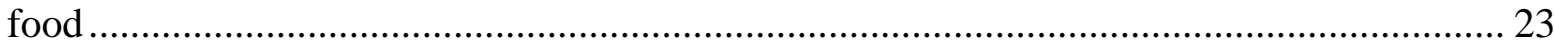

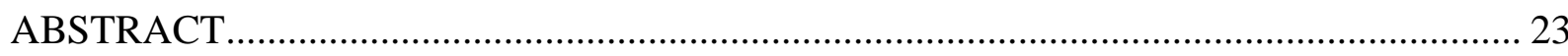

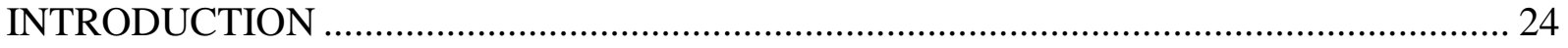

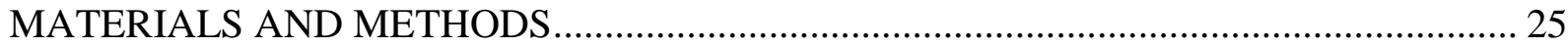

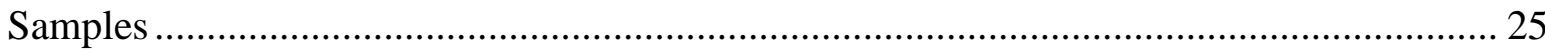

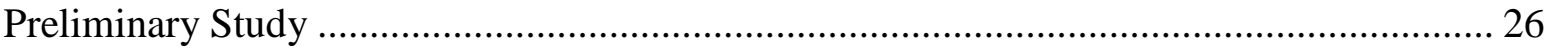

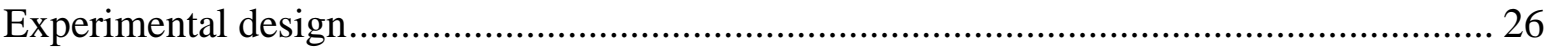

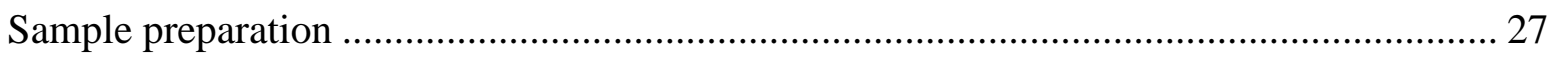

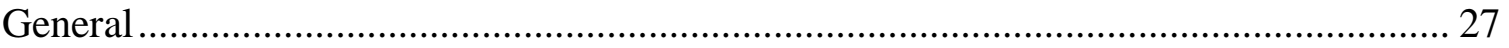

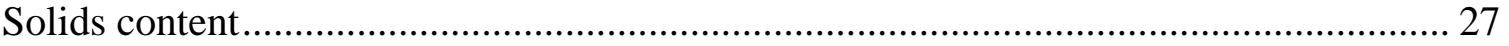




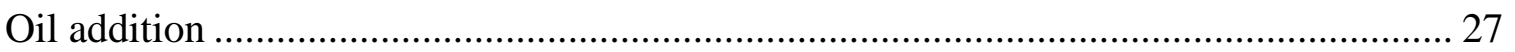

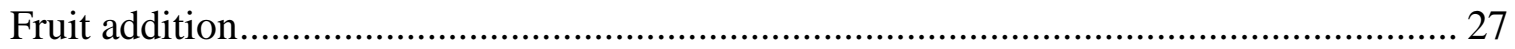

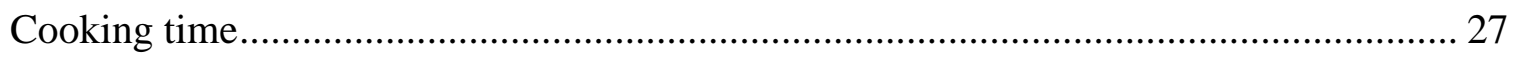

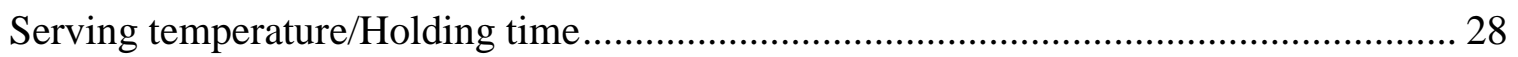

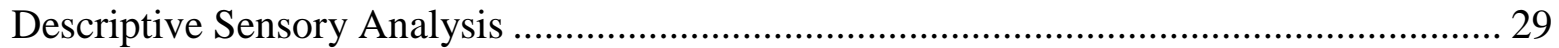

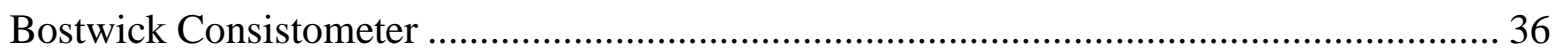

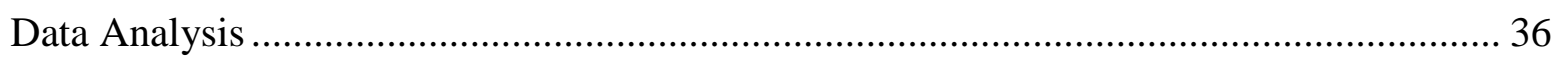

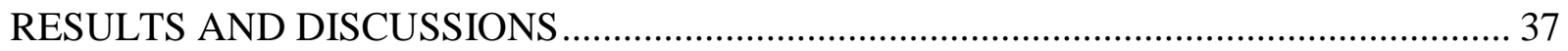

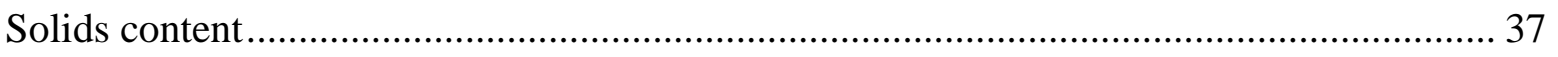

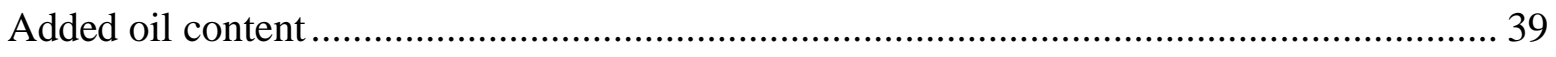

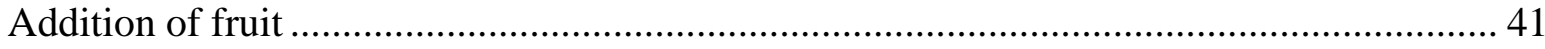

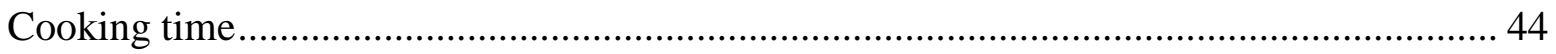

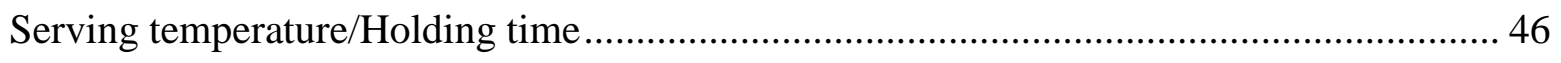

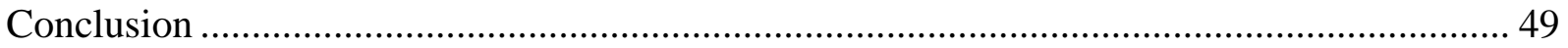

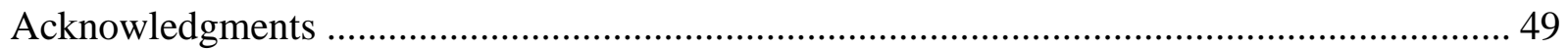

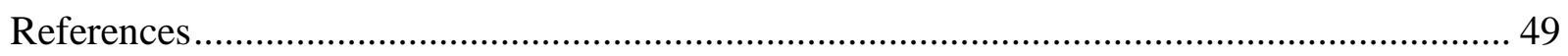

Appendix A - Ballot for porridge descriptive analysis ....................................................... 52

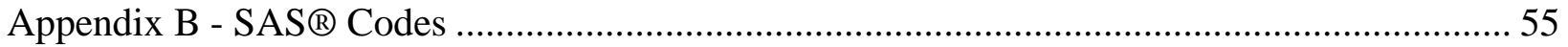




\section{List of Figures}

Figure 1-1Example meals prepared from fortified blended foods ....................................... 15 


\section{List of Tables}

Table 1-1 Typical components of fortified blended foods distributed by USAID and WFP* ...... 3

Table 1-2 Dairy nutrient needs by selected age and demographic groups for moderately

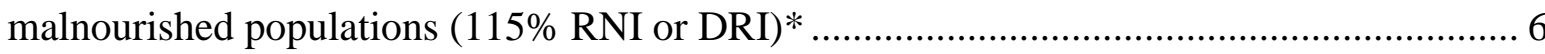

Table 1-3Comparison of vitamin and mineral premix levels in US CSB to proposed levels in FBFs intended for children aged 6-36 months and older children and adults*................. 9

Table 1-4 Recommended formulations for new USAID's FBFs* ......................................... 11

Table 1-5 Formulations for super cereal and super cereal plus ............................................. 12

Table 1-6 Quantities of vitamin and minerals added to WFP's FBFs .................................... 12

Table 1-7 Preparation variables for specific products $*$..................................................... 14

Table 2-1 List of ingredients and cooking procedures for each study .................................. 28

Table 2-2 Aroma, texture, flavor, and amplitude attributes, definitions, and references for

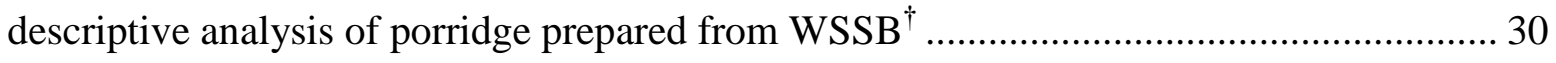

Table 2-3 Mean intensity scores $\uparrow$ and separation of sensory attributes of samples for the study of

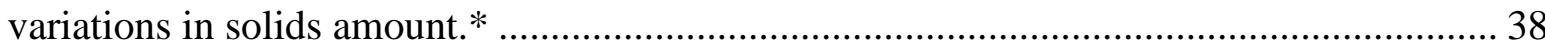

Table 2-4 Bostwick flow rates ${ }^{\dagger}$ of samples for the study of variations in solid amount. ${ }^{*}$............ 39

Table 2-5 Mean intensity scores $\uparrow$ and separation of sensory attributes of samples for the study of

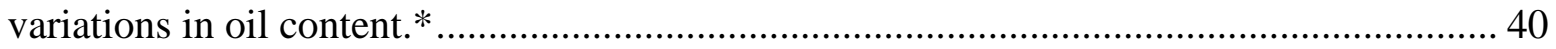

Table 2-6 Bostwick flow rates ${ }^{\dagger}$ of samples for the study of variations in oil.*........................ 41

Table 2-7 Mean intensity scores $\uparrow$ and separation of sensory attributes of samples for the study of

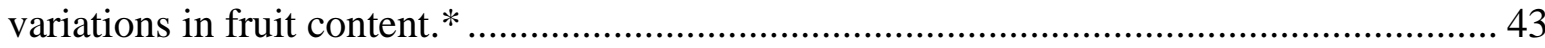

Table 2-8 Bostwick flow rates ${ }^{\dagger}$ of samples for the study of variations in fruit content. ............. 44

Table 2-9 Mean intensity scores $\uparrow$ and separation of sensory attributes of samples for the study of

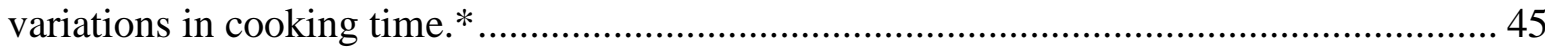

Table 2-10 Bostwick flow rates ${ }^{\dagger}$ of samples for the study of variations in cooking time. *........ 46

Table 2-11 Mean intensity scores $\dagger$ and separation of sensory attributes of samples for the study

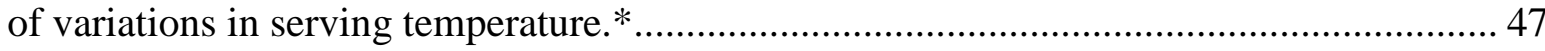

Table 2-12 Bostwick flow rates ${ }^{\dagger}$ of samples for the study of variations in serving temperature. 48 


\section{Chapter 1 - Literature Review}

\section{Consumer behavior related to food preparation}

Consumers have their own ways to cook food. Foods prepared by diverse people in various conditions are likely to be different in appearance, flavor or texture. The diversity among consumers is based on many factors including demographic and socio-economic status (Wilcock, Pun, Khanona, \& Aung, 2004). There are no rules for the preparation, handling and the storage of food in the home. These are controlled through the education of the consumers (Unusan, 2007). Redmond et al. (2003) indicated that food preparation is habitual and consumers' seem to be unaware of actions in their own kitchens. The familiarity of the food make consumers pay less attention to the instructions for preparing food. They usually do not follow the instructions because they think that a product is easy to cook and they usually cook it all the time. On the other hand, consumers read the directions and tend to follow the directions closely for the unfamiliar products (Levis et al., 1996).

Consumers make many food-handling errors during food preparation in their home and do so repeatedly, which can increase their risk of foodborne illness. Many consumers do not follow the cooking recommendations. For example most consumers determine the doneness of the meat using methods like cutting with a knife, poking with a utensil, visual inspection, tasting on following cooking time. There are few consumers who follow the recommendation by using a food thermometer to check the doneness of the meat (Anderson et al., 2004).

\section{Fortified blended foods}

Fortified blended foods (FBFs) are defined as a combination of cereal-legume-oil admixtures fortified with a range of vitamins and minerals, with the possible addition of a dairybased source of protein. The grains and legumes should be partially precooked in order to 
enhance their digestibility, denature antinutritional factors, and reduce the cooking time required (Wood et al.,2008). These foods need to be energy-dense and "rich in micronutrients", easily digestible and palatable, and able to be prepared relatively quickly, i.e. with minimal cooking (IASC, 2009).

\section{History of Fortified blended foods}

Fortified blended Foods (FBFs) were developed in the 1960s to serve as a protein-rich, micronutrient-dense food supplement for infants and young children (preschool-age children) in developing countries to improve child nutrition (Fleige et al., 2010; Pérez-Expósito \& Klein, 2009).Corn and wheat were used as the basic ingredients providing carbohydrates, and soy flour and non-fat dry milk were use as protein supplements. Products were designed to have approximately $25 \%$ of the dairy energy needs of young children. Corn-Soy Milk (CSM) and Wheat-Soy Milk (WSM) were the first two original formulations of FBFs developed in 1967. Corn-Soy Blend (CSB) was developed in the 1980s to replace CSM and WSM because of the increasing cost and shortage of non-fat dry milk which was a main component of CSM and WSM (Webb et al., 2011; Fleige et al., 2010; Pérez-Expósito \& Klein, 2009). There were some modifications which had been made to the FBFs in the early 1990s to reflect current thinking on recommended intakes and bioavailability of nutrients, but no significant work had been done since the 1960s to incorporate advances in food science and technology into new and improved products for food aid (Fleige et al., 2010). CSB is now the most commonly used of FBFs. Wheat-Soy Blend (WSB) is another FBF that has been used but at a much lower volume than CSB. CSM and WSM are still available but they are rarely distributed due to the cost constrain (Fleige et al., 2010). Corn soy blends (CSB) are fortified blended foods (FBF) used extensively by USAID implementing partners, including the World Food Program (WFP). FBFs produced in 
The United State have to meet the requirements from the United State Department of Agriculture (USDA), while the locally produced FBFs are controlled by organizations such as the WFP and UNICEF. The formulations for the CSB and WSB distributed by USAID comply with the USDA and WFP are presented in Table 1-1.

Table 1-1 Typical components of fortified blended foods distributed by USAID and WFP*

\begin{tabular}{lll}
\hline \multicolumn{1}{c}{ USAID } & \multicolumn{1}{c}{ WFP } \\
\hline CSB & \multicolumn{1}{c}{ WSB } & \multicolumn{1}{c}{ CSB } \\
\hline Corn meal, processed 69.9\% & Soy flour, defatted, toasted 21.8\% & Maize 80\% \\
Soy flour, defatted, toasted 21.8\% & Straight grade wheat flour 37.9\% & Whole soya 20\% \\
Soy bean oil 5.5\% & Wheat protein concentrate 35\% & Minerals and Vitamins 0.4\% \\
Vitamin antioxidant premix 0.1\% & Soy bean oil 4\% & \\
Mineral premix 3\% & Vitamin antioxidant premix 0.1\% & \\
& Mineral premix 3\% & \\
\hline
\end{tabular}

*Pérez-Expósito \& Klein, 2009; WFP (2012)

\section{Advantages of Fortified blended foods}

Fortified blended foods (FBFs) have been used for more than forty years as complementary foods for developing countries around the world because they have various advantages over the alternative. FBFs are shown to promote growth very well since they contain adequate calories and protein. They are also fortified with essential micronutrients which are important because these micronutrients cannot be obtained from a normal diet in many situations. FBFs are pre-cooked, and require short cooking time and only limited amounts of fuel. The preparation of FBFs is flexible and easy. Moreover, foods prepared from FBFs are highly digestible and easy for infants and young children to swallow. Additionally, the cost of FBFs is low when compared to their nutritional value and other micronutrient-rich commodities. The low cost of the foods maximizes coverage of the populations in low income countries and increases long-term sustainability (WFP, 2002; de Pee \&Bloem, 2009). 


\section{Target Population}

FBFs, especially CSB, have come to be used as "one-size-fit-all" products for a wide array of population groups (Fleige et al., 2010; Pérez-Expósito \& Klein, 2009).There are 5 population groups which are the most usual target groups for FBFs.

The children under 2 years of age are the first target group for FBFs. This period is known as the "window of opportunity". This is the period when good nutrition is important and the lack of right nutrition will have lifelong consequences (de Pee \& Bloem, 2009). The first two years of a child's life are the most important for growth and development. The early undernutrition can reduce physical and mental development during early childhood, which may affect school performance and attendance (Victora et al., 2008). Moreover, most of the damage caused by the early childhood undernutrition is irreversible including the growth of muscles and the development of the brain. Therefore, improving nutrition for children under 2 is the highest priority (de Pee \& Bloem, 2009; Omamo, Gentilini, \& Sandström, 2010).

The second target group is children who suffer moderate malnutrition due to limitations such as food insecurity, poverty and political instability (Johnston et al., 2011). Wasting and Stunting are 2 types of malnutrition. Wasting, or low-weight-for-height, is known as acute malnutrition. Wasting mostly happens because of food shortage and disease. Moderate wasting can be reversed, therefore, children with this malnutrition should be treated to prevent from getting severe wasting which has a high mortality rate. Stunting, or short-height for age, is a sign of acute malnutrition. Stunting develops in children before the age of 2 years and it is irreversible, so it should be prevented before requiring treatment by providing the right nutrients to young children (de Pee \& Bloem, 2009; Johnston et al., 2011).

The third target group is pregnant and lactating women. During their pregnancy and lactation, these women need food with high energy, protein and micronutrients content. Pregnant 
women require an additional $285 \mathrm{kcals} /$ day, and lactating women require an additional 500 kcals/day. Both pregnant and lactating women have increased needs for micronutrients, especially iron, vitamin A, iodine and folate, which are important for their and their infants' health (Clugston, 2002).

The fourth target group is people who are living with chronical illnesses such as HIV/AIDS and tuberculosis (TB). The combination of chronical illness and food insecurity can result in greater poverty, health risk and malnutrition. People with the chronical illness often lose the ability to earn income because of the illness itself and side effects of the treatment. Therefore, supporting food and nutrition to this target population is essential in order to recover their health and resume their productive lives (WFP, 2011).

The last target group is people who are suffering from micronutrient deficiencies. This group also includes people who are affected by disaster-related emergencies and people who require food assistance such as people who live in the drought location or have faced bad harvest periods (Johnston et al., 2011).Hence, supporting them with food and nutrition is important in order to decrease their starving and improve their health.

\section{Product Improvement}

For the past 4 decades, FBFs have been provided to individuals of all age groups with high nutrition needs, such as moderate malnourished individuals, pregnant and lactating women, people with chronically illness, and as a good source of micronutrient to general population (de

Pee \& Bloem, 2009; Fleige et al., 2010). However, FBFs have been argued not to be optimal for treating young children with malnutrition (de Pee \& Bloem, 2009; Skau et al., 2009) and not intended to serve as a generic vehicle for delivering micronutrients to all household members because each vulnerable group has different dairy nutrient needs, as shown in Table 1-2. 
Table 1-2 Dairy nutrient needs by selected age and demographic groups for moderately malnourished populations (115\% RNI or DRI)*

\begin{tabular}{|c|c|c|c|c|}
\hline Nutrient & $\begin{array}{c}\text { Infants } \\
\text { 6-11 months }\end{array}$ & $\begin{array}{c}\text { Children } \\
\text { 12-36 months }\end{array}$ & $\begin{array}{l}\text { Pregnant } \\
\text { women }\end{array}$ & $\begin{array}{l}\text { Lactating } \\
\text { Women }\end{array}$ \\
\hline \multicolumn{5}{|l|}{ Macronutrients } \\
\hline Energy (kcal) & 675 & 1000 & 2385 & 2600 \\
\hline Protein $(\mathrm{g})$ & 16 & 23 & 71 & 71 \\
\hline Fat $(\mathrm{g})$ & 31 & 30 & $20-35$ & $20-35$ \\
\hline \multicolumn{5}{|l|}{ Minerals (mg) } \\
\hline Calcium & 299 & 700 & 1150 & 1150 \\
\hline Chromium & 0.0115 & 0.0127 & 0.035 & 0.052 \\
\hline Copper & 0.253 & 0.391 & 1.15 & 1.495 \\
\hline Iodine & 0.104 & 0.104 & 0.23 & 0.23 \\
\hline Iron & 10 & 10.35 & 31 & 23 \\
\hline Magnesium & 62.1 & 69 & 253 & 310.5 \\
\hline Manganese & 0.69 & 1.38 & 2.3 & 2.99 \\
\hline Molypdenum & 0.0035 & 0.0196 & 0.0575 & 0.0575 \\
\hline Phosphorus & 316.25 & 529 & 805 & 805 \\
\hline Potassium & 805 & 3450 & 5405 & 5865 \\
\hline Selenium & 0.012 & 0.02 & 0.035 & 0.048 \\
\hline Sodium & 425.5 & 1150 & 1725 & 1725 \\
\hline Zinc & 5.75 & 7.13 & 8.05 & 9.2 \\
\hline \multicolumn{5}{|l|}{ Vitamins (mg) } \\
\hline Vitamin A (Retinol equivalent: RE) & 0.46 & 0.46 & 0.92 & 0.978 \\
\hline Vitamin $B_{1}$ (Thiamin) & 0.345 & 0.575 & 1.61 & 1.725 \\
\hline Vitamin $B_{2}$ (Riboflavin) & 0.46 & 0.575 & 1.61 & 1.84 \\
\hline Vitamin $B_{3}$ (Niacin) & 4.6 & 6.9 & 20.7 & 19.6 \\
\hline Vitamin $\mathrm{B}_{5}$ (Pantothenic acid) & 2.07 & 2.3 & 6.9 & 8.05 \\
\hline Vitamin $\mathrm{B}_{6}$ & 0.345 & 0.575 & 2019 & 2.3 \\
\hline Vitamin $B_{7}$ (Biotin) & 0.0069 & 0.0092 & 0.0345 & 0.0403 \\
\hline Vitamin $\mathrm{B}_{9}($ Folic acid $)$ & 0.054 & 0.101 & 0.406 & 0.338 \\
\hline Vitamin $B_{12}$ & 0.0008 & 0.001 & 0.003 & 0.0032 \\
\hline Vitamin $\mathrm{C}$ & 34.5 & 34.5 & 63.25 & 80.5 \\
\hline Vitamin $D_{3}$ & 0.0115 & 0.0173 & 0.0173 & 0.0173 \\
\hline Vitamin E & 5.75 & 5.75 & 11.5 & 8.63 \\
\hline Vitamin K & 0.0115 & 0.0173 & 0.0633 & 0.0748 \\
\hline
\end{tabular}

*Webb (2011)

Abbreviations: RNI, Recommended Nutrient Intake; DRI, Dietary Reference Intake.

The current FBFs are CSB13 and WSB15. The different between these 2 products is the type of cereal that is used in the formulation. Corn is used in CSB13, and bulgur is used as a basic ingredient in WSB15. Both products have been noted that they do not perform well in the prevention of malnutrition or promote growth since they contain inadequate micronutrients and a low level of essential fatty acids and fats. FBFs become quite thick when cooked in the field, therefore mothers usually prepare diluted porridges for their infants and young children. These 
diluted porridges have insufficient energy and nutrient density to support children's growth (Fleige et al., 2010). Skau et al. (2009) reported that FBFs contain high levels of antinutrients, especially phytate which inhibit the absorption of many micronutrients such as iron and zinc. Huffman (2009), de Pee \&Bloem (2009) also noted that FBFs contain a relatively large amount of fiber, especially when prepared from non-dehulled soybeans, maize or wheat. Fiber can increase the bulk of the food, filling the child and reducing their ability to consume sufficient energy. Moreover, they do not contain animal-source protein which increasingly appears to be important for the growth of young malnourished children (de Pee \& Bloem, 2009).

\section{Recommendations for product changes}

There are several recommendations for FBFs in order to make this product meet the needs of multiple vulnerable groups.

Extrusion cooking is one of the processes that has been recommended to use to produce FBFs. Cooked porridge from extruded FBFs will have lower consistency, so mothers do not have to dilute porridge for their children and children would get enough energy and nutrient density to support their growth. Moreover, FBFs manufactured with extrusion process require less cooking time and less need for fuel, which is frequently in short supply in relief situations (Fleige et al., 2010).

Grillenberger et al. (2003) noted that although FBFs have soy protein which already has a good protein profile, the addition of an animal-source protein will contribute further to appropriate utilization and lean mass accretion. Replacing some of soy flour with a dairy ingredient would potentially improve absorption of micronutrients such as iron and zinc (Fleige et al., 2010).This has led to the addition of milk powder or other dairy derivatives to FBFs. World Food Programme (WFP) has already upgraded specifications for FBFs by adding milk 
powder into the blends which is called "super cereal plus". Webb et al. (2011) also suggested USDA to increase protein quantity in FBFs by adding whey protein concentrate (WPC).

Increasing fat and energy content is another recommendation for FBFs. Increasing fat content of the food can increase the energy density of the diet, support neurodevelopment and increase the absorption of fat-soluble vitamins. Moreover, fat can also improve the texture, flavor, and aroma of the food (Fleige et al., 2010). Therefore, the recommended FBFs should be prepared and consumed with fortified vegetable oil (FVO) at defined volumes (15 g oil per $50 \mathrm{~g}$ dry matter and in increment of that ratio) which results in higher fat and energy content (Webb et al., 2011).

Upgrading the micronutrient composition of FBFs is another major recommendation in order to improve the quality of FBFs. Overall, micronutrient levels should be set higher than in the past. The micronutrient requirement for each vulnerable group, such as infants, young children and pregnant and lactating women, is significantly different. Therefore, Fleige et al. (2010) developed a micronutrient simulation model to determine the appropriate fortification levels for FBFs for 2 specific population groups that are children aged 6-36 months and older children and adults, including pregnant and lactating women (Table 1-3).

Moreover, Webb et al. (2011) recommended that a flavor enhancer might be added to formulations of FBFs. The addition of a sweet additive can enhance taste and acceptability, which is important when we try to increase the consumption among sick and undernourished children. It is also suggested by the industry that toasting the corn germ would provide and enhanced sweet flavor. 
Table 1-3Comparison of vitamin and mineral premix levels in US CSB to proposed levels in FBFs intended for children aged 6-36 months and older children and adults*

\begin{tabular}{|c|c|c|c|c|c|}
\hline Nutrient & $\begin{array}{c}\text { Levels in US } \\
\text { CSB } \\
\text { (per 100 g) }\end{array}$ & $\begin{array}{c}\text { Proposed } \\
\text { levels in FBF } \\
\text { intended for } \\
\text { children } \\
\text { aged 6-36 } \\
\text { months } \\
(\text { per } 100 \mathrm{~g} \text { ) }\end{array}$ & \% Change & $\begin{array}{c}\text { Proposed } \\
\text { levels in FBF } \\
\text { intended for } \\
\text { older } \\
\text { children and } \\
\text { adults } \\
(\text { per } 100 \mathrm{~g})^{\dagger \neq}\end{array}$ & $\%$ Change \\
\hline \multicolumn{6}{|l|}{ Minerals premix } \\
\hline Calcium, mg & 775 & 693 & -11 & 657 & -15 \\
\hline Magnesium, mg & 83 & 33 & -60 & 45 & -46 \\
\hline Zinc, mg & 4.6 & 15 & 226 & 7 & 52 \\
\hline Sodium, mg & 320 & 219 & -32 & 327 & 2 \\
\hline Phosphorous, mg & 399 & 339 & -15 & 441 & 11 \\
\hline Iron, mg & 15.1 & 15.4 & 2 & 10 & -34 \\
\hline Iodine, $\mu \mathrm{g}$ & 57 & 164 & 188 & 113 & 98 \\
\hline Potassium, $\mathrm{mg}^{\S}$ & 0 & 2654 & NA & 2699 & NA \\
\hline \multicolumn{6}{|l|}{ Vitamins premix } \\
\hline Vitamin $\mathrm{B}_{1}$ (Thiamin), mg & 0.22 & 0.36 & 65 & 0.45 & 106 \\
\hline Vitamin $B_{2}$ (Riboflavin), mg & 0.39 & 0.66 & 69 & 0.57 & 46 \\
\hline Vitamin $B_{3}$ (Niacin), mg NE & 5 & 6.4 & 28 & 7.31 & 46 \\
\hline Vitamin $B_{5}$ (Pantothenic & & & & & \\
\hline acid), mg & 2.5 & 2.8 & 12 & 2.23 & -11 \\
\hline Vitamin $\mathrm{B}_{6}, \mathrm{mg}$ & 0.14 & 0.35 & 150 & 0.67 & 378 \\
\hline Vitamin $\mathrm{B}_{9}$ (Folic acid), $\mu \mathrm{g}$ & 198 & 99.5 & -50 & 217 & 10 \\
\hline Vitamin $B_{12} \mu \mathrm{g}$ & 1.32 & 1.3 & -4 & 1.29 & -2 \\
\hline Vitamin $\mathrm{C}, \mathrm{mg}$ & 40 & 55 & 38 & 28 & -30 \\
\hline Vitamin $A, \mu g$ & 771 & 734 & -5 & 377 & -51 \\
\hline Vitamin $D, \mu \mathrm{g}$ & 5 & 9.2 & 84 & 8.1 & 62 \\
\hline Vitamin E, mg & 5 & 5.1 & 2 & 4.6 & -8 \\
\hline
\end{tabular}

*Fleige et al.(2010)

${ }^{\dagger}$ New proposed premix levels were calculated by subtracting intrinsic levels of micronutrients in cereal-soy blends from simulation model results. The intrinsic estimates are based on data from the USDA's Nutrient Database for Standard Reference, release 21 using 75\% of the lowest levels reported in CSB, wheat soy blend, and corn soy milk. ${ }^{\ddagger}$ These values are not final and may be modified in the future for practical reasons, e.g., palatability, stability, and cost.

${ }^{\S}$ Potassium is not added to current US PL 480 CSB premix.

Abbreviations: CSB, corn soy blend; FBF, fortified blended food.

de Pee \& Bloem (2009) suggested to use cornmeal derived from dehulled and degermed corn and soy flour derived from dehulled soy beans in order to decrease fiber content of FBFs. Infants and young children typically eat smaller amount of high-fiber bulky cereals, which reduces the intake amount of food and affects their nutritional status. There was a study reported that infants' intake of a cereal product decreased significantly from $42 \pm 23 \mathrm{~g} / \mathrm{d}$ to $34 \pm 23 \mathrm{~g} / \mathrm{d}$ 
$(p<0.01)$ as the fiber in the cereals increased from $1.8 \%$ to $8 \%$, respectively (Davisson et al., 1996). Therefore, using dehulled and degermed corn and dehulled soy beans in FBFs formulations would increase children's consumption and their energy intake.

The Food Aid Quality Review (FAQR) recommends the use of other cereals such as sorghum, millets and rice, instead of the traditional cereals which are corn and wheat, in the production of FBF (USDA ERS 2012). Sorghum is looked at as a potential alternative because of a number of advantages over corn and wheat. Sorghum is mostly a non-Genetically Modified Organisms (GMO) crop which allows it to be used in many countries around the world that have banned the use of GMO products. It is priced competitively with other food aid grains. Moreover, when it is processed properly, it contains a level of carbohydrates similar to CSB and also has a higher level of protein, fat and some micronutrients (Dicko et al, 2006). The study of extruded fortified sorghum soy blend (SSB) by Padmanabhan (2013) showed that sorghum can be used as a viable corn-substitute in FBFs. The extruded SSB has a high energy density (410 $\mathrm{kcal} / 100 \mathrm{~g}$ ) with a consistency comparable to the new recommendation for fortifications in Tufts report to USAID.

\section{Newly developed fortified blended foods}

Webb et al. (2011) reported recommendations for the composition of modified FBFs for USAID which are called CSB14 and WSB16 (Table 1-4). The new FBFs provide approximately $400 \mathrm{kcal}$ in a $100 \mathrm{~g}$ ration (dry weight), and the total energy rises to over $650 \mathrm{kcal}$ when served with the defined volume of oil ( $30 \mathrm{~g}$ of fortified vegetable oil to $100 \mathrm{~g}$ of FBF). The primary beneficiary groups for the new FBFs are children under 5 year old, underweight lactating or pregnant women and also adults with HIV/AIDS. 
Table 1-4 Recommended formulations for new USAID's FBFs*

\begin{tabular}{|c|c|c|}
\hline Ingredient & CSB14 & WSB16 \\
\hline & \multicolumn{2}{|c|}{ Percent } \\
\hline Corn meal & 67.5 & - \\
\hline Bulgur wheat & - & 53.0 \\
\hline Gluten & - & 16.5 \\
\hline WPC80 & 3.0 & 3.0 \\
\hline Soy flour & 21.0 & 19.0 \\
\hline \multirow[t]{2}{*}{ Vegetable oil } & 5.5 & 5.5 \\
\hline & \multicolumn{2}{|c|}{ Per $100 \mathrm{~g}$} \\
\hline Energy (kcal) & 387 & 350 \\
\hline Protein $(\mathrm{g})$ & 17.7 & 28 \\
\hline Fat (g) & 9.0 & 6.8 \\
\hline
\end{tabular}

*Webb et al. (2011)

Abbreviations: CSB14, corn soy blend version 14; WSB16, wheat soy blend version 16; FBF, fortified blended food; WPC80, whey protein concentrate with $80 \%$ protein content

The World Food Programme (WFP) also improved the specifications for their FBFs which are super cereal $(\mathrm{CSB}+)$ and super cereal plus $(\mathrm{CSB}++)$. The $\mathrm{CSB}+$ has an improved micronutrient content. This product is for general use for different individuals including older children, pregnant and lactating women, and people suffering from HIV/AIDS. On the other hand, CSB++ has been improved for young children (6-24 months) and moderately malnourished children. It has a higher fat content and better protein quality by addition of $8 \%$ milk powder. The formulations and targeted micronutrients for the two products are presented in Table 1-5 and Table 1-6, respectively. 
Table 1-5 Formulations for super cereal and super cereal plus

\begin{tabular}{|c|c|c|}
\hline Ingredient & $\mathrm{CSB}^{\dagger}$ & CSB++ \\
\hline \multicolumn{3}{|c|}{ Percent } \\
\hline Maize & 78.3 & 58.3 \\
\hline Soya bean & 20.0 (Whole soya bean) & 20.0 (De-hulled soya bean) \\
\hline Dried Skim milk powder & - & 8.0 \\
\hline Refine soya bean oil & - & 3.0 \\
\hline Sugar & - & 9.0 \\
\hline Vitamin/Mineral & 0.20 & 0.20 \\
\hline Dicalcium Phosphate Anhydrous & 1.23 & 1.23 \\
\hline Potassium chloride & 0.27 & 0.27 \\
\hline \multicolumn{3}{|c|}{ Per $100 \mathrm{~g}$} \\
\hline Energy (kcal) & 380 & 420 \\
\hline Protein $(\mathrm{g})$ & 14 & 16 \\
\hline Fat $(\mathrm{g})$ & 6 & 9 \\
\hline
\end{tabular}

${ }^{\dagger} \mathrm{WFP}(2014 \mathrm{a})$

*WFP (2014b)

Abbreviations: CSB+, Super cereal; CSB++, Super cereal plus.

Table 1-6 Quantities of vitamin and minerals added to WFP's FBFs

\begin{tabular}{|c|c|}
\hline Nutrient & CSB+ and CSB++ \\
\hline \multicolumn{2}{|l|}{ Minerals premix } \\
\hline Calcium, mg & 362 \\
\hline Zinc, mg & 5 \\
\hline Phosphorous, mg & 280 \\
\hline $\operatorname{Iron}(\mathrm{a})$; Ferrous fumarate, $\mathrm{mg}$ & 4 \\
\hline Iron(b); Iron-sodium EDTA, mg & 2.5 \\
\hline Iodine, $\mu \mathrm{g}$ & 40 \\
\hline Potassium, mg & 140 \\
\hline \multicolumn{2}{|l|}{ Vitamins premix } \\
\hline Vitamin $\mathrm{B}_{1}$ (Thiamin), mg & 0.2 \\
\hline Vitamin $\mathrm{B}_{2}$ (Riboflavin), mg & 1.4 \\
\hline Vitamin $B_{3}$ (Niacin), mg NE & 8 \\
\hline Vitamin $\mathrm{B}_{5}$ (Pantothenic acid), mg & 1.6 \\
\hline Vitamin $\mathrm{B}_{6}, \mathrm{mg}$ & 1 \\
\hline Vitamin $B_{9}$ (Folic acid), $\mu \mathrm{g}$ & 110 \\
\hline Vitamin $B_{12} \mu \mathrm{g}$ & 2 \\
\hline Biotin, $\mu \mathrm{g}$ & 8.2 \\
\hline Vitamin $\mathrm{C}, \mathrm{mg}$ & 90 \\
\hline Vitamin A, IU & 3460 \\
\hline Vitamin D IU & 441.6 \\
\hline Vitamin E, mg & 8.3 \\
\hline Vitamin $K, \mu g$ & 30 \\
\hline
\end{tabular}




\section{Preparation and use of fortified blended foods}

FBFs, that are currently used, are partially pre-cooked foods. They are designed to be cooked, fried or baked to complete their digestibility. WFP (2002) suggested that the cooking time for FBFs should vary from 2 to 15 minutes depending on the kind of preparation required. Vegetables, seasoning and other additives are used in order to improve the palatability and to increase the nutritive value of the final product. Rowe et al. (2009) reported that African people added sugar and vegetable oil to their meal. Cinnamon, herbs, or banana were often added to the Guatemalan recipes.

Thin or thick porridges are the most common dishes prepared from cereal-based products (Rowe et al., 2008; Moussa et al, 2011). The difference between thick and thin porridge is the concentration of the flour used in the preparation. The thick porridges, known by different name such as tô, tuwo, aseda, ugali, muddle, are solid-like and consumed as a starchy staple food at meal. On the other hand, thin porridges are fluid-like or semi-fluid, consumed in the morning as breakfast or served to lactating mothers and young children. For thin porridges preparation, flavoring or other food items such as milk, fruits or spices are often added to improve the taste of the porridge (Anglani, 1998; Moussa et al., 2011). Although there are widespread uses of FBFs for making porridge, the cooking methods varied from household to household. Rowe et al. (2008) reported that beneficiaries in Uganda and Guatemala prepare porridges with concentration ranges of $10 \%$ to $31 \%$ (wt/wt) in water and cook them from 5 to 53 minutes, with a mean of 26 minutes. Table 1-7 shows the summary of specific preparation variables including formulation, cooking time and cooking temperature for principal products prepared from USAID commodities in Guatemala and Uganda. 
Table 1-7 Preparation variables for specific products*

\begin{tabular}{|c|c|c|c|c|c|}
\hline Product & Ingredients & Variable & Mean & Min & Max \\
\hline \multirow[t]{5}{*}{ Thin porridge } & \multirow{5}{*}{$\begin{array}{l}\text { Corn-soy-blend } \\
\text { or Soy-fortified } \\
\text { corn-meal }\end{array}$} & Concentration of dry ingredient $(\% \mathrm{wt} / \mathrm{wt})$ & 14.3 & 10.5 & 26.3 \\
\hline & & Water temperature at addition $\left({ }^{\circ} \mathrm{C}\right)$ & 66.5 & 36.0 & 94.0 \\
\hline & & Maximum temperature during cooking $\left({ }^{\circ} \mathrm{C}\right)$ & 94.4 & 88.0 & 97.0 \\
\hline & & Boiling time (min) & 23.8 & 4.0 & 46.0 \\
\hline & & Total cooking time (min) & 26.4 & 5.0 & 53.0 \\
\hline \multirow[t]{5}{*}{ Thick mush } & \multirow{5}{*}{$\begin{array}{l}\text { Corn-soy-blend } \\
\text {,Soy-fortified } \\
\text { cornmeal, or } \\
\text { corn-meal }\end{array}$} & Concentration of dry ingredient $(\% \mathrm{wt} / \mathrm{wt})$ & 23.8 & 19.2 & 31.3 \\
\hline & & Water temperature at addition $\left({ }^{\circ} \mathrm{C}\right)$ & 73.2 & 50.0 & 87.0 \\
\hline & & Maximum temperature during cooking $\left({ }^{\circ} \mathrm{C}\right)$ & 94.9 & 89.0 & 98.0 \\
\hline & & $\begin{array}{l}\text { Time to addition of second portion of dry } \\
\text { ingredients (min) }\end{array}$ & 8.7 & 3.5 & 14.0 \\
\hline & & Total cooking time (min) & 12.7 & 5.0 & 20.0 \\
\hline \multirow{2}{*}{$\begin{array}{l}\text { Various } \\
\text { products }\end{array}$} & \multirow{2}{*}{$\begin{array}{l}\text { Vegetable oil } \\
\text { for frying }\end{array}$} & Maximum temperature during cooking $\left({ }^{\circ} \mathrm{C}\right)$ & 193.6 & 127.0 & 280 \\
\hline & & Total cooking time $(\mathrm{min})$ & 5.1 & 2.0 & 9 \\
\hline
\end{tabular}

*Rowe et al. (2008)

Beside porridges, there are many dishes that can be prepared from FBFs. Tortillas and beverages are other common dishes observed in Guatemala (Rowe et al., 2008). WFP (2002) also listed the recipes which can be prepared from FBFs. These recipes include porridges, beverages, simple breads or cakes, roasted products, flitters, and other preparations such as steamed dumplings, banana leaf rolls and cookies. The examples of food prepared from FBFs are shown in Figure 1-1. 


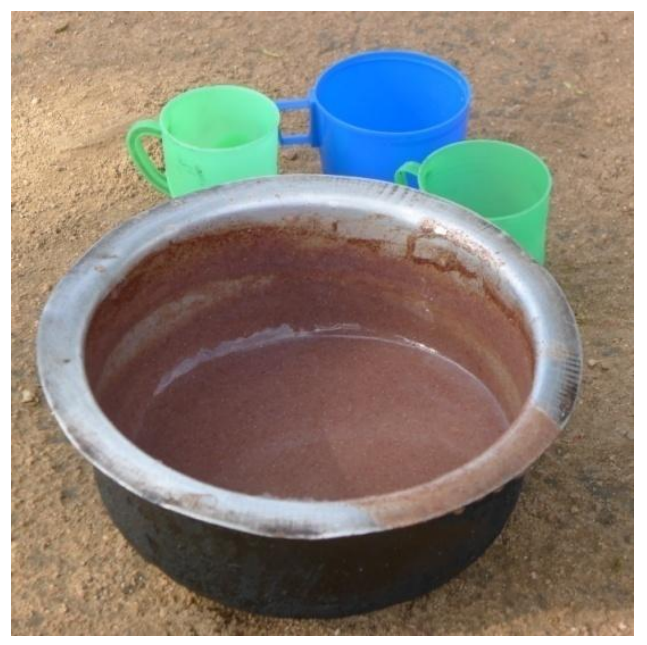

a

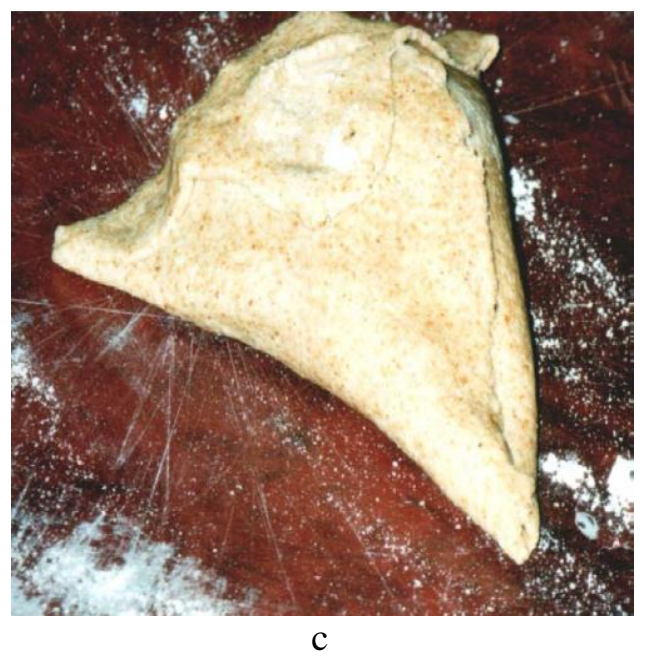

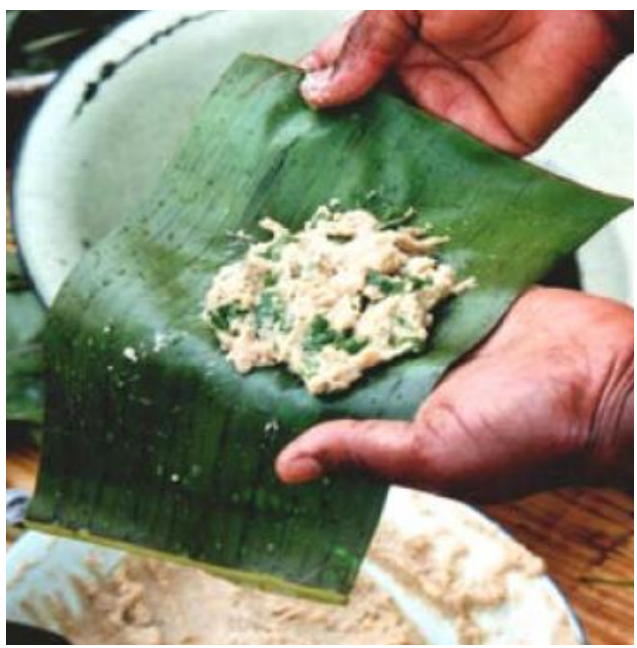

b

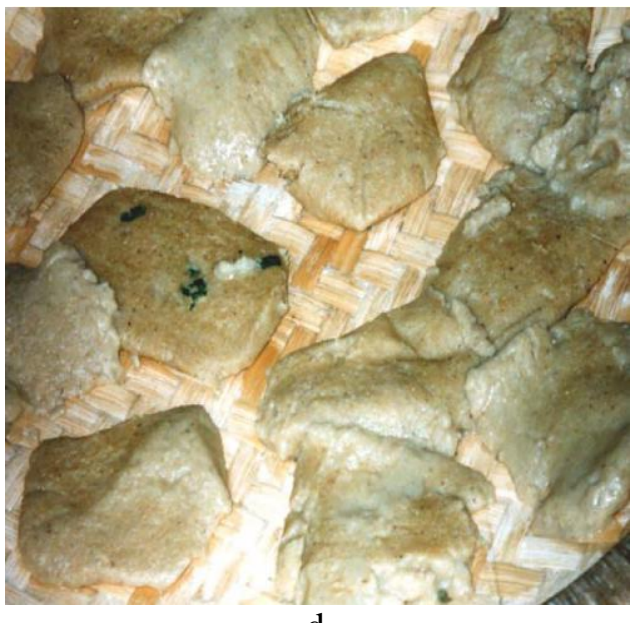

d

Figure 1-1Example meals prepared from fortified blended foods

(Source: WFP, 2002)

a - Porridge

b - Banana Leaf Rolls

c - Unleavened Bread

d - Fermented Steam Cake 


\section{Sensory evaluation of fortified blended foods}

\section{Descriptive analysis}

There are few studies on descriptive analysis of FBFs. A recent study was done on sensory characteristics of Sorghum-soy blend (SSB), corn-soy blend (CSB) and whole-corn soy blend (WCSB) which were developed by extrusion process (Padmanabhan, 2013). This study aimed to evaluate fortified blended foods (FBFs) when prepared with an increased solids amount (from $11.75 \%$ to $20 \%$ solids), as recommended by Webb et al. (2011) to increase energy density of the products. All blends were prepared as porridges at $11.75 \%$ and $20 \%$ solids content and evaluated by a highly trained panel on aroma, flavor, and texture characteristics. The scale used was an intensity scale with 0.5 increments from $0=$ none to $15=$ extremely high. The greatest differences between the $11.75 \%$ and the $20 \%$ solids were found in the texture of porridges. Thickness, particle amount, and lump size attributes were all increased in the $20 \%$ solids

porridges. Moreover, porridges at $20 \%$ solids content typically had an increase in starch and toasted flavor, and reduced sorghum or corn flavor compared to the products at $11.75 \%$ solids (Padmanabhan, 2013).

Kehlet et al. (2011) chose Quantitative Descriptive Analysis (QDA) to identify and quantify sensory properties of porridges prepared from original CSB and CSB with either skim milk powder (SMP) or whey protein concentrate (WPC). A trained panel developed a descriptive language and divided the sensory attributes into groups of odor, color, texture, flavor and taste. The original CSB was perceived as grayer in color, and more mealy/dry than CSB with milk proteins. The addition of milk protein increased the sweetness the CSB, which could be positive in terms of acceptability in children. 
The flavor profile analysis technique was chosen to evaluate sensory properties of products prepared from CSB that had been extruded at different temperatures $\left(155\right.$ and $\left.171^{\circ} \mathrm{C}\right)$. A highly train panel was used to describe the aroma, flavor and aftertaste associated with each product. The higher temperature of extrusion resulted in higher aroma and flavor amplitudes of the products (Maga \& Lorenz, 1978).

Deliza et al. (1990) conducted a descriptive analysis on a new weaning food based on sweet corn dehydrated pulp by using 10 mothers as panelists because the products were to be used in infant feeding. The panelists developed 5 sensory attributes to describe the products including appearance, fresh corn flavor, off-flavor, consistency, and global impression. The scale used was a nine-point scale. The results of sensory evaluation shown that all 3 formulated products developed in this study were similar in most of sensory attributes except consistency. The product with higher content of dehydrated sweet corn pulp was found to be higher in consistency.

\section{Consumer studies}

Rowe et al. (2008) conducted a field study in Uganda, Malawi, and Guatemala to obtain data on preparation, and usage of fortified blended foods provided by the US Agency for International Development. The observational and interview data were collected from more than 100 households in 32 different villages spread across different regions of the three countries. Thin or thick porridges appeared to be the most common dishes prepared from cereal-based products, with a wide range of concentration from $10 \%$ to $31 \%(\mathrm{wt} / \mathrm{wt})$ in water. Sugar, vegetable oil, and other seasoning were commonly added to the meals. Cooking times for porridges ranged from 5 to 53 minutes. Moreover, many private voluntary organizations that often implement child feeding program might provide recipes that vary in cooking procedures. 
Several ways to evaluate consumer liking and preferences of products exist. This is true with FBFs, especially porridge, because people who use this products are different in age group, economic status and level of education.

For the adults, this may be the acceptability test, where the consumers may be asked to taste porridges and evaluate acceptability of the products based on a 5-point, 7-point, or 9-point hedonic scale with the lowest score representing "dislike extremely" and the highest score representing "like extremely". Consumers might be given a short training before evaluating session in order to clarify the objective and the methodology of the study (Amegovo et al.; 2014, Jackson, 2013; Moussa et al., 2011).

There are many ways to conduct the consumer study on children. Older children, may be asked to taste the products and evaluate their acceptability by using an uncomplicated scale such as a 3-point hedonic scale or a facial hedonic scale (Jackson, 2013). Moreover, the verbal anchors associated with the scale should be more child-friendly such as used the term "super good" instead of the term "like extremely" and used the term "super bad" instead of the term “dislike extremely” (Popper \& Kroll, 2005).

The taste preferences of newborns and infants can be investigated by using behavioral measures. Mothers or caregivers were asked to rate their child's degree of liking based on their perception using a traditional hedonic scale such as a 7-point and a 9-point hedonic scale (Popper \& Kroll, 2005; Amegovo et al., 2014). The amount of products that was consumed by the children can be used to determine the product acceptability. Valid International (2014) noted that food supplement was considered acceptable if children consumed at least $75 \%$ of the serving and if less than $10 \%$ of adverse effect cases were reported. 


\section{Research Objectives}

From past studies, it is apparent that fortified blended foods can be used by multiple population groups. The use of products by people in different locations and also by people with low literacy and few resources for measuring and timing during preparation resulted in the variations on cooking methods from household to household. Therefore, such products must have a high tolerance regarding various cooking methods. However, it is unclear whether FBFs have tolerance to variations in cooking procedures or not. In order to clarify this problem, this study intended to determine the tolerance to preparation variations for a porridge product made as a FBF intended for food aid. There are 5 different variations in ingredients and cooking procedures selected in this study 1) Solids content; 2) Added oil content; 3) Addition of fruit; 4) Cooking time; and 5) Serving temperature or holding time.

\section{References}

Amegovu, A. K., Ogwok, P., Owor, S., Yiga, P., Musalima, J. H., Mandha, J. (2014). Sensory acceptability of sorghum peanut blend (SPB) and corn soy blend plus (CSB ) by young children with moderate acute malnutrition in karamoja, uganda. Journal of Food Research, $3(2), \mathrm{p} 17$.

Anderson, J. B., Shuster, T. A., Hansen, K. E., Levy, A. S., Volk, A. (2004). A camera's view of consumer food-handling behaviors. Journal of the American Dietetic Association, 104(2), 186-191.

Anglani, C. (1998). Sorghum for human food - A review. Plant Foods for Human Nutrition, 52(1), 85-95. doi:10.1023/A:1008065519820

Clugston, G.A. (2002). Food and Nutrition needs in Emergencies. Available at: http://www.unhcr.org/45fa745b2.pdf Accessed 9 September 2014.

Davidsson L, Mackenzie J, Kastenmayer P, et al.(1996). Dietary fiber in weaning cereals: a study of the effect on stool characteristics and absorption of energy, nitrogen, and minerals in healthy infants. J Pediatr Gastroenterol Nutr,22:167-179. 
de Pee, S., Bloem, M. W. (2009). Current and potential role of specially formulated foods and food supplements for preventing malnutrition among 6-to 23-month-old children and for treating moderate malnutrition among 6-to 59-month-old children. Food \& Nutrition Bulletin, 30(3), S434.

Deliza, R., Sgarbieri, V.C., Rosenthal, A. (1990). Formulation, Nutritive Value and Sensory Evaluation of a New Weaning Food Based on Sweet Corn(Nutrimaiz) Dehydrated Pulp. Journal of Nutritional Science and Vitaminology, 36, 587-597.

Dicko, M. H., Gruppen, H., Traoré, A. S., Voragen, A. G., Van Berkel, W. J. (2006). Review: Sorghum grain as human food in africa: Relevance of starch content and amylase activities. African Journal of Biotechnology, 5, 384-395.

Fleige, L. E., Moore, W. R., Garlick, P. J., Murphy, S. P., Turner, E. H., Dunn, M. L., Schaefer, S. E. (2010). Recommendations for optimization of fortified and blended food aid products from the united states. Nutrition Reviews, 68(5), 290-315.

Grillenberger, M., Neumann, C., Murphy, S., Bwibo, N., van't Veer, P., Hautvast, J., West, C.. 2003. Food supplements have a positive impact on weight gain and the addition of animal source foods increases lean body mass of Kenyan schoolchildren. J Nutr 133(11 Suppl 2):3957S-64S.

IASC (Inter-Agency Standing Committee). (2009). Nutrition in Emergencies. Harmonized Training Package prepared by the IASC Nutrition Cluster's Capacity Development Working Group. Available from http://www.unscn.org/en/gnc_htp/modul.php?modID=2.

Jackson, J. C., Weatherspoon, L., Nnyepi, M., Malete, L., Mokgatlhe, L., Lyoka, P., Bennink, M. (2013). Sorghum bean composite porridge nutritional quality and acceptability. Nutrition \& Food Science, 43(5), 453-461.

Johnston, K., Ramos, B., \& Weissenborn, E.(2011). Fortified blended foods. Available at: http://blogs.ubc.ca/fnh490/files/2011/02/FortifiedBlendedFoods.pdf. 25 August 2014.

Kehlet, U., Kaelig, P., Hausner, H., Bredie, W. L., Allesen-Holm, B. H. (2011). Sensory characteristic of corn soya blend and the effects of milk protein replacement. African Journal of Food Science, 5(4), 200-207.

Levis, P.A, Chambers, E. IV, Chambers, D.H., and Hollingsworth, M.G. 1996. Consumer use of package directions for familiar and unfamiliar products. In. Gelinas, A.D. (Ed.) "Sensory techniques used in conducting packaging research with consumers" STP 1316, ASTM, West Conshohocken, PA pp 16-24

Maga, J.A., Lorenz, K. (1978). Sensory and Functional Properties of Extruded Corn-Soy Blend. Journal of Food Science and Technology, 11(4), 185-187. 
Moussa, M., Qin, X., Chen, L. F., Campanella, O. H., Hamaker, B. R. (2011). High- quality instant sorghum porridge flours for the west african market using continuous processor cooking. International Journal of Food Science and Technology, 46(11), 2344-2350. doi:10.1111/j.1365-2621.2011.02755.x

Omamo, S., Gentilini, U., Sandström, S. (2010). Revolution: From food aid to food assistanceinnovations in overcoming hunger. World Food Programme, Rome,

Padmanabhan, N. (2013). A Novel Mechanism for Delivering Nutrition: Sorghum Based Fortified Blended Foods using Extrusion(Doctoral dissertation, Kansas State University).

Pérez-Expósito, A. B., Klein, B. P. (2009). Impact of fortified blended food aid products on nutritional status of infants and young children in developing countries. Nutrition Reviews, 67(12), 706-718.

Popper, R., Kroll, J.J.(2005). Issue and Viewpoints Conducting Sensory Research with Children. Journal of Sensory Studies, 20, 75-87.

Redmond E. C., Griffth C. J. (2003). A comparison and evaluation of research methods used in consumer food safety studies. International Journal of consumer Studies, 27, 17-33.

Rowe, J. P., Ogden, L. V., Pike, O. A., Steele, F. M., Dunn, M. L. (2009). Effect of end- user preparation methods on vitamin content of fortified humanitarian food-aid commodities. Journal of Food Composition and Analysis, 22(1), 33-37. doi:10.1016/j.jfca.2008.09.004

Rowe, J.P., Brodegard, W.C., Pike, O. A., Steele, F. M., Dunn, M. L. (2008). Storage, preparation, and usage of fortified food aid among guatemalan, ugandan, and malawian beneficiaries: A field study report. Food and Nutrition Bulletin, 29(3), 213-220.

Skau, J., Belachew, T., Girma, T., Woodruff , B. (2009). Outcome Evaluation Study of the Targeted Supplementary Food (TSF) Program in Ethiopia. Report to the World Food Programme. Addis Ababa. Mimeo.

Unusan, N. (2007). Consumer food safety knowledge and practices in the home in turkey. Food Control, 18(1), 45-51.

USDA. (2012). Feed grains: Year book table: Domestic and International prices, Table 9 Corn and sorghum: Average prices received by farmers, United States, Table 13 Sorghum: Cash prices at principal markets. Economic Research Service, Washington DC, USA. Available at:http://www.ers.usda.gov/contact-us.aspx\#.UXWJGkrtp48. Accessed 28 August 2014.

Valid International. (2006). Community-based Therapeutic Care (CTC). Available at: http://www.concernusa.org/media/pdf/2007/10/ctc_manual_v1_oct06.pdf Accessed 20 September 2014. 
Victora, C.G., Adair, L., Fall, C., Hallal, P.C., Martorell, R., Richter, L., Sachdev, H.S. (2008) Maternal and Child Undernutrition: Consequences for Adult Health and Human Capital. The Lancet, 371(9606): 340-357.

Webb P, Rogers B, Rosenberg I, Schlossman N, Wanke C, Bagriansky J, Sadler K, Johnson Q, Tilahun J, Masterson A, Narayan A. (2011). Delivering Improved Nutrition : Recommendations for Changes to U.S.Food Aid Products and Programming. Boston, MA: Tufts University.

Wilcock, A., Pun, M., Khanona, J., Aung, M. (2004). Consumer attitudes, knowledge and behaviour: A review of food safety issues. Trends in Food Science \& Technology, 15(2), 5666.

Wood, J., M. Palazzo, P. Dijkhuizen. (2008). Fortified Blended Foods: From a Nutritional Objective to a Development Opportunity. The Contribution of WFP to the Production and Use of Blended Foods in Developing Countries. Report to WFP. Rome. Mimeo (original date 2006; Revised June 2008).

World Food Programme. (2014a). Technical Specifications for the manufacture of: Super Cereal Corn Soy Blend. Available at: http://documents.wfp.org/stellent/groups/public/documents/manual_guide_proced/wfp25 1131.pdf Accessed 9 September 2014.

World Food Programme. (2014b). Technical Specifications for the manufacture of: Super Cereal Plus Corn Soy Blend. Available at: http://documents.wfp.org/stellent/groups/public/documents/manual_guide_proced/wfp26 2697.pdf Accessed 9 September 2014

World Food Programme (2012) Food Quality Control. Energy Density Concept. WFP. Available at:http://foodquality.wfp.org/FoodNutritionalQuality/Energy/tabid/114/Default.aspx?Pag eContentID=447. Accessed 23 September 2014.

Whole Food Programme. (2011). HIV, AID, TB and Nutrition. Available at: http://documents.wfp.org/stellent/groups/public/documents/newsroom/wfp244302.pdf Accessed 4 September 2014. 


\title{
Chapter 2 - Tolerance testing for cooked porridge made from a sorghum based fortified blended food
}

\begin{abstract}
Products that will be prepared by consumers must be tolerant to various cooking procedures that those consumers may use. Five different variations in ingredients and cooking procedures were selected to evaluate the tolerance of cooked porridges prepared from a whole sorghum soy fortified blended food (WSSB). Tolerance was tested by measuring properties using descriptive analysis and viscosity using a Bostwick consistometer. Thirty-five attributes including aroma, texture, flavor, and amplitude were used to describe the sensory properties of the porridges. The results showed that most sensory properties were only marginally affected by variations in ingredients or procedures. However, as expected, large differences occurred in some properties such as thickness and adhesiveness when solids content varied or sweetness and fruit flavor when fruit was added. Moreover, Bostwick flow rate can be used as an indication of thickness characteristics of porridges. Tolerance testing showed that the sensory properties of WSSB had high tolerance to variations in cooking procedures, which means that the product can be modified during preparation by consumers without having a major impact on most sensory properties.
\end{abstract}




\section{INTRODUCTION}

Foods intended to be prepared by consumers must be tolerant to various procedures for preparation in order to maintain a similar appearance, flavor, or texture. Consumers tend to cook food according to their accustomed procedures and they may not follow the preparation instructions. The preparation, handling and the storage of food in home are controlled to an extent through the consumers' education (Unusan, 2005). Levis et al. (1996) indicated that consumers pay less attention to the instructions if they are familiar with the products. Garcia et al. (2010) showed that even when products need to be prepared to a specific thickness to meet needs for a health condition, preparers rarely followed directions and the product varied greatly in its properties.

Fortified blended foods (FBFs) are a combination of cereal-legume-oil mixtures fortified with a range of micronutrients and the possible addition of a dairy-based source of protein (Wood et al., 2008). FBFs promote growth because they contain adequate calories, protein, and also are fortified with essential micronutrients, which cannot be obtained from a normal diet (WFP, 2002; de Pee \& Bloem, 2009). FBFs have been used as a complementary food for developing countries around the world for more than forty years. Corn soy blend (CSB) is one of the most commonly used FBFs and have been used as "one-size-fits-all" for an array of population groups (Fleige et al., 2010; Pérez-Expósito \& Klein, 2009). The target population for FBFs are divided into 5 groups: 1) children under 2 year of age; 2) children who suffering moderate malnutrition; 3) pregnant and lactating women; 4) people with chronic illness including HIV/AIDS and tuberculosis; and 5) people who suffer from micronutrient deficiencies.

Porridges are the most common dishes prepared from cereal-based products such as FBFs (Rowe et al., 2008; Moussa et al., 2011). The World Food Programme (2002) suggested that the cooking time for FBFs should be varied from 2 to 15 minutes depending on the kind of 
preparation required. Rowe et al. (2008) reported that people in Guatemala and Uganda prepared porridges with a wide concentration range of $10 \%$ to $31 \%$ (wt/wt) and cooked the porridge for 5 to 53 minutes. Flavoring or other food items such as milk, sugar, fruits, spices or vegetable can be added to thin porridge to improve the taste of the porridge (Anglani, 1998; Moussa et al., 2011). Modifications, such as addition of oil and sugar, often are included in use recommendations for FBFs to improve energy and nutrient profiles (de Pee \& Bloem, 2009). In addition, those authors noted maintaining appropriate "texture, consistency, and homogeneity" is an important issue in developing modifications of specially formulated foods.

This study evaluated the tolerance to preparation and ingredient variations for a porridge prepared from a new FBF intended for use in a food aid program. The specific objective was to determine the variation in sensory characteristics and Bostwick consistometer values of cooked porridge made from a sorghum-based FBF with five variations in cooking procedures and ingredients: 1) solids content; 2) added oil content; 3) addition of fruit; 4) cooking time; and 5) serving temperature or holding time.

\section{MATERIALS AND METHODS}

\section{Samples}

Whole White Sorghum Soy Blend (WSSB), a fortified, extruded, ground cooked "cereal" was selected as the FBFs for this study. The sample consisted of a base formulation made of $76.3 \%$ of whole white sorghum flour (AgVanced Enterprises, New Cambria, KS, USA) with $23.7 \%$ of defatted soy flour (ADM protein specialties division, Decatur, IL, USA). Pre-weighed samples of each formulation were blended in a ribbon mixer (Wenger Manufacturing Co., Sabetha, KS, USA) for 5 minutes before it was extruded. The premix was then extruded at a high 
energy of $450 \mathrm{rpm}$ with $20 \%$ process moisture. Extruded products were dried at $104^{\circ} \mathrm{C}$ and then cooled at room temperature on a cooling belt. Post-extrusion, the dried extrudates were ground and fortified with $3.0 \%$ of whey protein concentrate (Davisco Foods International, Inc, Le Sueur, MN, USA), $3.0 \%$ of minerals and $0.1 \%$ of vitamin premix (Research Products Co., Salina, KS, USA) and 5.5\% of vegetable oil (The J.M. Smucker Company, Orrville, OH, USA) using a Hobart Blender N50 (Hobart Corporation, Troy, OH., USA).

\section{Preliminary Study}

Field observations in 30 households in Tanzania in 2014 showed that porridges typically were eaten by children for breakfast. The porridges frequently were cooked with varying water amounts, the addition of sugar or milk, were cooked for differing times, and may be held in thermos-type containers for eating later throughout the day. The preliminary observations showed the cooking methods for porridges varied from household to household and showed the need to study the tolerance of FBFs to various cooking procedures.

\section{Experimental design}

Five variations in cooking procedures (1) solids content; 2) cooking time; 3) serving temperature/holding time; 4) added oil content; and 5) addition of fruit) were selected to evaluate the tolerance of cooked porridge (Table 2-1). These variations were chosen based on both the field observations (water amount/solids content, addition of sugar, holding time/temp) and knowledge of other widely used ingredients such as oil and fruit. In many situations when using FBFs, oil is provided as a supplementary energy source and participants are encouraged to add up to $30 \%$ oil to the FBF. In addition, recipes for porridges made from FBFs suggest addition of sugar, oil, and seasonal fruit to improve nutrient composition or palatability (North American Millers Assoc., 2014). 


\section{Sample preparation}

\section{General}

A weighed FBF flour amount (150g) was added to boiling water $(850 \mathrm{ml})$, brought back to a boil, and cooked for 5 minutes while continuously stirring with a wooden spoon. The sample was removed from the stovetop and cooled at room temperature to $45^{\circ} \mathrm{C}$, typical consumption temperature by infants (Mouquet et al., 2006).

\section{Solids content}

The porridges were prepared at 10-30\%, solids FBF (flour) content (Table 2-1).

\section{Oil addition}

Soy-bean oil (ConAgra Foods, Omaha, NE, USA) was added to $150 \mathrm{~g}$ of the FBF flour at $0 \%, 10 \%, 20 \%, 30 \%$ and $40 \%$ of the weight of the FBF flour (Table 2-1) and mixed. The FBF flour and oil mixture were added to the boiling water and cooked and held as in the general recipe.

\section{Fruit addition}

Banana was selected as the fruit to be used in this study because of its availability and consumption rate (Adeyemi, 2009). When the standard sample was removed from the stovetop, ripe mashed banana (Del Monte, San Francisco, CA, USA) was added to the porridge at 0\%, $10 \%, 20 \%, 30 \%$, and $40 \%$ of FBF flour weight. Cooling continued as for the general product.

\section{Cooking time}

The porridges were prepared according to the general method except that when the porridge was brought back to a boil, it was cooked for $2,5,10,20$ or 30 minutes while continuously stirring with a wooden spoon. Cooling then proceeded as in the general method. 


\section{Serving temperature/Holding time}

The porridges were prepared according to the general method except that cooling was to $70^{\circ} \mathrm{C}, 45^{\circ} \mathrm{C}$, and $30^{\circ} \mathrm{C}$, approximately 20,55 , and 120 minutes, respectively.

Table 2-1 List of ingredients and cooking procedures for each study

\begin{tabular}{|c|c|c|c|c|c|}
\hline Study & $\begin{array}{c}\text { WSSB } \\
(\% \mathrm{wt} / \mathrm{wt})\end{array}$ & $\begin{array}{c}\text { Oil } \\
(\% \text { of WSSB })\end{array}$ & $\begin{array}{c}\text { Banana } \\
\text { (\% of WSSB })\end{array}$ & $\begin{array}{c}\text { Cooking time } \\
(\text { min. })\end{array}$ & $\begin{array}{c}\text { Serving } \\
\text { temperature } \\
\left({ }^{\circ} \mathbf{C}\right)\end{array}$ \\
\hline \multirow[t]{5}{*}{ Solid content } & 10 & - & - & 5 & 45 \\
\hline & 15 & - & - & 5 & 45 \\
\hline & 20 & - & - & 5 & 45 \\
\hline & 25 & - & - & 5 & 45 \\
\hline & 30 & - & - & 5 & 45 \\
\hline \multirow[t]{5}{*}{ Oil content } & 15 & 0 & - & 5 & 45 \\
\hline & 15 & 10 & - & 5 & 45 \\
\hline & 15 & 20 & - & 5 & 45 \\
\hline & 15 & 30 & - & 5 & 45 \\
\hline & 15 & 40 & - & 5 & 45 \\
\hline \multirow[t]{5}{*}{ Fruit content } & 15 & - & 0 & 5 & 45 \\
\hline & 15 & - & 10 & 5 & 45 \\
\hline & 15 & - & 20 & 5 & 45 \\
\hline & 15 & - & 30 & 5 & 45 \\
\hline & 15 & - & 40 & 5 & 45 \\
\hline \multirow[t]{5}{*}{ Cooking time } & 15 & - & - & 2 & 45 \\
\hline & 15 & - & - & 5 & 45 \\
\hline & 15 & - & - & 10 & 45 \\
\hline & 15 & - & - & 20 & 45 \\
\hline & 15 & - & - & 30 & 45 \\
\hline \multirow{3}{*}{$\begin{array}{c}\text { Serving } \\
\text { temperature }\end{array}$} & 15 & - & - & 5 & 30 \\
\hline & 15 & - & - & 5 & 45 \\
\hline & 15 & - & - & 5 & 70 \\
\hline
\end{tabular}




\section{Descriptive Sensory Analysis}

Descriptive sensory analysis was conducted to evaluate the aroma, texture, flavor, and amplitude of all samples using a trained descriptive panel at the Sensory Analysis Center at Kansas State University. This panel consisted of six highly trained panelists who have had $120 \mathrm{~h}$ of general descriptive analysis training, over 2,000 $\mathrm{h}$ of evaluation experience with a wide array of food products, including grain products. Thirty-five attributes including aroma, texture, flavor, and amplitude were used to describe samples (Table 2-2). Approximately $50 \mathrm{~g}$ of porridge was served in a $120 \mathrm{ml}$ Styrofoam cup labeled with a three digit code to each panelist. The porridge samples were individually evaluated on an intensity-point scale $(0=$ none to $15=$ extremely high) with 0.5 increments, using a randomized complete block design. Each sample was prepared and evaluated in triplicate. Five samples were evaluated per day. The panelists used deionized water, carrots and unsalted crackers to cleanse their palate between samples. 
Table 2-2 Aroma, texture, flavor, and amplitude attributes, definitions, and references for descriptive analysis of porridge prepared from WSSB ${ }^{\dagger}$

\begin{tabular}{|c|c|c|}
\hline Attribute & Definition & Reference \\
\hline \multicolumn{3}{|l|}{ Aroma } \\
\hline Overall grain & $\begin{array}{l}\text { A general term used to describe the } \\
\text { aromatic which includes musty, dusty, } \\
\text { slightly brown, slightly sweet and is } \\
\text { associated with harvested grains and dry } \\
\text { grain stems. }\end{array}$ & $\begin{array}{l}\text { Cereal Mix }(\text { dry })=7.5 \\
\text { Mix 1/2 cup of each General Mills Rice Chex, Wheaties and } \\
\text { Quaker Quick Oats. Put in a blender and "pulse" blend into } \\
\text { small particles. Serve } 2 \text { Table spoons in medium snifter } \\
\text { covered with a watch glass. }\end{array}$ \\
\hline Musty overall & $\begin{array}{l}\text { A combination of one or more aromatic } \\
\text { impressions characterized to some degree } \\
\text { as being somewhat dry, dusty, damp, } \\
\text { earthy, stale, sour, or moldy. If } \\
\text { identifiable, attribute will be listed. }\end{array}$ & $1,2,4$ Trimethoxybenzene $50,000 \mathrm{ppm}=4.0$ \\
\hline Cardboard & $\begin{array}{l}\text { The aromatics associated with cardboard or paper } \\
\text { packaging. }\end{array}$ & $\begin{array}{l}\text { Cardboard soaked in water, covered with watch glass }=7.5 \\
\text { Place } 2 \text { " square piece of cardboard in a medium snifter. Cover } \\
\text { with } 1 / 2 \text { cup of water. Cover with a watch glass. }\end{array}$ \\
\hline Toasted & A moderately browned/baked impression. & $1 / 4$ cup of crushed Cheerios $=7.0$ \\
\hline Brown & $\begin{array}{l}\text { A rich full round aromatic impression } \\
\text { always characterized as some degree of } \\
\text { darkness generally associated with } \\
\text { attributes such as toasted nutty, roasted, } \\
\text { sweet. }\end{array}$ & $\begin{array}{l}\text { Bush Pinto Beans (canned) }=6.0 \\
\text { Drain beans and rinse with de-ionized water. Place one } \\
\text { table spoon in a medium snifter at room temperature. }\end{array}$ \\
\hline Overall fruity & $\begin{array}{l}\text { Aromatics associated with fruits including } \\
\text { citrus and non-citrus. }\end{array}$ & $\begin{array}{l}\text { Diluted Welch's White Grape Juice }(1: 1)=5.5 \\
\text { Serve } 1 / 2 \text { cup in medium snifter. }\end{array}$ \\
\hline
\end{tabular}


Table 2-2 (Continued)

Attribute

\section{Definition}

Sweet, green, fruity aromatics reminiscent of banana

\section{Reference}

Banana

McCormick Imitation Banana Extract in $2 \%$ milk $=6.0$

Mix $1 / 8$ tsp extract in 1 cup $2 \%$ milk. Serve $1 / 2$ cup in medium sn Ripe Banana $=12.0$

Mash ripe banana and place in $1 \mathrm{oz}$ cup. Serve 1 teaspoon in a medium covered snifter.

\section{Texture/Mouthfeel}

Thickness/Viscosity A measure of the consistency of the product when manipulated against roof of mouth with tongue.

Particles

Lumpy (size)

The perception of small pieces relatively harder than surrounding product.

The perception of the size of lumps within sample (small to large).

Uniformity of size

The degree to which all of the particles are the same size rather than a mixture of different sizes.

Adhesiveness
Dillon's Whipping Cream $=4.0$

Jell-O Instant Vanilla Pudding $=7.0$

Jif Creamy Peanut Butter $=14.0$

Cheerios $=3.0$

Hunt's Snack Pack Tapioca Pudding $=3.0$

Kozy Shack Rice Pudding $=9.0$

1 cup of Hunt's Snack Pack No Sugar Added Vanilla Pudding with $1 / 2$ cup of Baker's Angel Flake Coconut Sweetened = 12.0

Kroger Low Fat Cottage cheese $=6.5$

Quaker Yellow Corn Meal = 12.0

Cooked Quaker Quick Oats $=3.5$

$1 / 2$ cup of oats in 1 cup of boiling water, cook for 1 minute, stirring occasionally.

Kozy Shack Rice Pudding $=10.0$

Jif Peanut Butter $=13.0$
Degree to which sample adheres to mouth/ palette surfaces during mastication. 
Table 2-2 (Continued)

\section{Attribute}

Gumminess

Residual particles

Mouth drying

Overall mouthcoating The perception of a film left in the mouth

\section{Flavor}

Overall grain after swallowing that maybe described as one or more of the following: slick, sticky, or starchy.

A sticky, glue-like impression perceived in product during mastication.

Related to the perceived fat content. Refers to the intensity of the oily feeling in the mouth when the product is manipulated between tongue and palate

The amount of small pieces left around the teeth and mouth surfaces after swallowing. coconut until evenly distributed in the pudding.

The drying, puckering sensation on the tongue and other mouth surfaces.

A general term used to describe the light dusty/musty aromatics associated with grains such as corn, wheat, bran, rice and oats.
Reference

Kozy Shack Rice Pudding $=6.0$

Babybel Regular cheese $=5.0$

Hellman's regular Mayo $=7.5$

Cheerios $=3.0(4$ pieces $)$

General Mills Wheaties $=7.0$ (3 pieces)

1 cup of Hunt's Snack Pack No Sugar Added Vanilla Pudding with $1 / 2$ cup of Baker's Angel Flake Coconut Sweetened = 9.0

Post Shredded Wheat $($ Spoon size $)=10.0(1$ piece $)$

$0.03 \%$ Alum solution $=1.5$

$0.050 \%$ alum solution $=2.5$

1 cup of Hunt's Snack Pack No Sugar Added Vanilla Pudding with $1 / 2$ cup of Baker's Angel Flake Coconut Sweetened $=5.0$ Hunt's Snack Pack Tapioca Pudding $=5.0$

Philadelphia Fat Free Cream Cheese $=9.5$

Cereal Mix $=8.0$

Mix $1 / 2$ cup of each General Mills Rice Chex, Wheaties and Quaker Quick Oats. Put in a blender and "pulse" blend into small particles. 
Table 2-2 (Continued)

Attribute

\begin{tabular}{ll}
\hline Sorghum & $\begin{array}{l}\text { A slightly sweet, musty/dusty aromatic with } \\
\text { characteristics of chalkiness, starch and } \\
\text { astringency. May also include slightly green } \\
\text { and bitter }\end{array}$ \\
Soy & Flavor associated with soybeans or soy pro \\
Musty & Aromatics associated with wet grain and damp \\
& \\
Starch & $\begin{array}{l}\text { The dry aromatic associated with starch and } \\
\text { starch based grain product such as wheat, } \\
\text { rice, oat and other grains }\end{array}$
\end{tabular}

Toasted

\section{Reference}

Bob's Red Mill sweet white sorghum flour $=5.0$

Unsalted soy nuts $=4.5$

Cooked American Beauty elbow macaroni $=5.0$

Boil 1 cup of pasta in 3 cups water Cook 6 minutes, stirring occasionally. Drain and put in cups.

Cereal Mix (dry) $=7.0$

Mix $1 / 2$ cup of each General Mills Rice Chex, Wheaties and Quaker Quick Oats. Put in a blender and "pulse" blend into small particles.

Cooked American Beauty elbow macaroni $=9.0$

Boil 1 cup of pasta in 3 cups water. Cook 6 minutes, stirring occasionally. Drain and put in cups.

$3.5 \%$ Argo corn starch gel in water $=11.0$

Heat $250 \mathrm{ml}$ of water. Dissolve $17.5 \mathrm{~g}$ of cornstarch in $250 \mathrm{ml}$ of cool water and slowly add to the heated water. Bring mix to a boil over medium-high heat, stir constantly. Let boil for 1 minutes, remove from heat and let cool.

Post Shredded Wheat $($ Spoon size $)=3.5$

General Mills Cheerios = 7.0 
Table 2-2 (Continued)

\section{Attribute}

\section{Definition}

Reference

\begin{tabular}{|c|c|c|}
\hline Brown & $\begin{array}{l}\text { A rich full round aromatic impression } \\
\text { always characterized as some degree of } \\
\text { darkness generally associated with } \\
\text { attributes such as toasted nutty, roasted, } \\
\text { sweet }\end{array}$ & $\begin{array}{l}\text { Bush Pinto Beans (canned) }=3.0 \\
\text { Drain beans and rinse with de-ionized water. }\end{array}$ \\
\hline Overall fruity & An aromatic blend reminiscent of a variety of fruits. & Diluted Welch's White Grape Juice $(1: 1)=5.5$ \\
\hline Banana & Sweet, green, fruity aromatics reminiscent of banana & $\begin{array}{l}1 / 8 \text { tsp of McCormick Imitation Banana Extract in } 1 \text { cup of } \\
2 \% \text { milk }=2.5 \\
\text { Mashed ripe Banana }=10.0\end{array}$ \\
\hline Sweet & $\begin{array}{l}\text { A fundamental taste factor of which sucrose is } \\
\text { typical. }\end{array}$ & $\begin{array}{l}2 \% \text { Sucrose Solution }=2.0 \\
4 \% \text { Sucrose Solution }=4.0\end{array}$ \\
\hline Bitter & $\begin{array}{l}\text { The fundamental taste factor of which caffeine or } \\
\text { quinine is typical. }\end{array}$ & $\begin{array}{l}0.01 \% \text { Caffeine Solution }=2.0 \\
0.02 \% \text { Caffeine Solution }=3.5 \\
0.035 \% \text { Caffeine Solution }=5.0\end{array}$ \\
\hline Sour & $\begin{array}{l}\text { A fundamental taste factor of which citric acid in } \\
\text { water is typical. }\end{array}$ & $\begin{array}{l}0.015 \% \text { Citric Acid Solution }=1.5 \\
0.025 \% \text { Citric Acid Solution }=2.5\end{array}$ \\
\hline Astringent & $\begin{array}{l}\text { The drying, puckering sensation on the tongue and } \\
\text { other mouth surfaces. }\end{array}$ & $\begin{array}{l}0.03 \% \text { Alum solution }=1.5 \\
0.050 \% \text { alum solution }=2.5 \\
0.100 \% \text { alum solution }=5.0\end{array}$ \\
\hline
\end{tabular}


Table 2-2 (Continued)

Attribute

\section{Amplitude}

Impact

Blendedness

Fullness

Longevity

Overall amplitude
The maximum overall sensory impression during early mastication.

(Scored either at initial consumption or the first few seconds in order to provide time for the sensory properties to bloom.)

The combination of flavor notes that interact to create an equally balanced character in the product. Flavors appropriate to the product will enhance blendedness intensity as long as they are well balanced. Flavors not appropriate to the product will detract from this intensity.

The degree of a general perception of robust flavor that rounded with body. This includes an initial high impact with multi-dimensional presentation in aromatics and flavor notes.

The time that the full integrated sensory experience sustains itself in the month and after swallowing.

The integration of impact, balance, blended, complexity, and longevity that presents a unified, full sensory experience.
Post Shredded Wheat=3.5

Nabisco Wheat Thins Crackers $=5.5$

General Mills Wheaties $=4.0$

General Mills Corn Chex $=10.0$

General Mills Wheaties $=8.0$

Cooked Quaker Quick Oats = 3.0

$1 / 2$ cup of oats in 1 cup of boiling water, cook for 1 minute, stirring occasionally.

White Bread $=3.0$

Sourdough bread $=7.5$

Jif Creamy Peanut Butter $=10.0$

Multi-grain whole wheat bread $=11.0$

N/A

${ }^{\dagger} 0$-15-point numeric scale with 0.5 increments was used to rate the intensities of the samples and refer 


\section{Bostwick Consistometer}

Viscosity was measured using a Bostwick Consistometer (CSC Scientific Company Inc., Fairfax, VA., USA) as indicated for FBFs (USDA, 2005). After the samples reached the serving temperature (as specified for each treatment), $100 \mathrm{ml}$ of product was poured into the compartment of the Bostwick Consistometer. After a 30 second settling time, the gate was released and the slurry was allowed to flow through the graduated trough. Bostwick values were recorded after 1 min (USDA 2005). Measurements for each product were obtained in triplicate.

\section{Data Analysis}

Data for each study (solids content, oil addition, fruit addition, cooking time, serving temperature/holding time) was analyzed separately. Analysis of variance (ANOVA) was used to test whether differences occurred $(p \leq 0.05)$ for each of the 35 sensory characteristics and Bostwick values across the porridge samples for each study. Fisher's protected Least Significant Difference (LSD), post-hoc means separation at the 5\% level of significance was used to determine which samples were significantly different for each of the measured properties. Statistical analyses were performed with SAS® statistical software (version 9.2, SAS Institute Inc., Cary, NC) using PROC GLIMMIX. 


\section{RESULTS AND DISCUSSIONS}

\section{Solids content}

Twenty two of the 35 attributes were significantly different $(p \leq 0.05)$ across samples (Table 2-3). As expected, the variations in solids content caused a major impact on texture of the cooked porridge especially apparent in the thickness, adhesiveness and gumminess which could impact the ability to swallow the product by young children. Bostwick measurements (Table 2-4) also supported the finding that the increase in the solids concentration increased thickness of the product. Cooked porridge with higher solids content (higher than $15 \%$ solids content) may not be suitable for complementary feeding because it was too thick. Vieu et al. (2001) suggested that porridge with a Boswick flow closer to $12 \mathrm{~cm}$. is more typical for complementary feeding. Although solids content had a major impact on the sensory attributes and thickness this is unlikely to be a problem in actual feeding. The preliminary field study showed that caregivers typically cooked the porridge to a thickness they thought was appropriate for their infant, adding more water or FBF flour when needed.

Small differences were found in most of the flavor and amplitude characteristics and the product with a higher solid content generally was similar to the $15 \%$ solids "control" product. Most differences were detected between higher solids and the $10 \%$ solids content, which resulted in a thin product. For starch flavor the differences were larger. Porridge with higher solids concentration had more starch granules and that resulted in more intense starch flavor of the product. It is unknown how these differences would impact acceptance of the product, especially since the solids content often would be adjusted in actual feeding settings to be appropriate for the intended recipient. 
Table 2-3 Mean intensity scores $\uparrow$ and separation of sensory attributes of samples for the study of variations in solids amount.*

\begin{tabular}{|c|c|c|c|c|c|c|}
\hline & \multirow{2}{*}{ Attribute } & \multicolumn{5}{|c|}{ Solids content $(\% \mathrm{wt} / \mathrm{wt})$} \\
\hline & & 10 & 15 & 20 & 25 & 30 \\
\hline \multirow[t]{7}{*}{ Aroma } & Grain Overall & 6.64 & 7.08 & 6.92 & 6.88 & 6.94 \\
\hline & Musty Overall & 3.22 & 3.30 & 3.22 & 3.01 & 3.28 \\
\hline & Cardboard & 3.44 & 3.61 & 3.39 & 3.36 & 3.58 \\
\hline & Toasted & 2.31 & 2.39 & 2.28 & 2.44 & 2.47 \\
\hline & Brown & 1.86 & 2.04 & 1.94 & 2.03 & 2.03 \\
\hline & Overall Fruity & 0.00 & 0.00 & 0.00 & 0.00 & 0.00 \\
\hline & Banana & 0.00 & 0.00 & 0.00 & 0.00 & 0.00 \\
\hline \multirow{10}{*}{$\begin{array}{l}\text { Texture/ } \\
\text { Mouthfeel }\end{array}$} & Thickness & $3.44^{\mathrm{e}}$ & $5.48^{\mathrm{d}}$ & $8.92^{\mathrm{c}}$ & $11.81^{\mathrm{b}}$ & $13.64^{\mathrm{a}}$ \\
\hline & Particles & $1.75^{\mathrm{c}}$ & $3.04^{\mathrm{b}}$ & $4.11^{\mathrm{a}}$ & $3.57^{\mathrm{b}}$ & $4.08^{\mathrm{a}}$ \\
\hline & Lumpy (size) & $1.22^{\mathrm{c}}$ & $6.82^{\mathrm{b}}$ & $9.94^{\mathrm{a}}$ & $7.30^{\mathrm{b}}$ & $6.68^{\mathrm{b}}$ \\
\hline & Uniformity of size & $11.28^{\mathrm{a}}$ & $8.09^{\mathrm{b}}$ & $6.17^{\mathrm{c}}$ & $7.01^{\mathrm{b}}$ & $7.50^{\mathrm{b}}$ \\
\hline & Adhesiveness & $2.03^{\mathrm{e}}$ & $6.06^{\mathrm{d}}$ & $9.31^{\mathrm{c}}$ & $10.57^{\mathrm{b}}$ & $12.28^{\mathrm{a}}$ \\
\hline & Gumminess & $1.44^{\mathrm{e}}$ & $5.07^{\mathrm{d}}$ & $7.61^{\mathrm{c}}$ & $9.25^{\mathrm{b}}$ & $11.81^{\mathrm{a}}$ \\
\hline & Oily Mouthfeel & $0.50^{\mathrm{b}}$ & $0.86^{\mathrm{a}}$ & $0.64^{\mathrm{ab}}$ & $0.57^{\mathrm{b}}$ & $0.42^{\mathrm{b}}$ \\
\hline & Residual particles & $1.75^{\mathrm{d}}$ & $3.12^{\mathrm{c}}$ & $4.17^{\mathrm{ab}}$ & $3.87^{\mathrm{b}}$ & $4.44^{\mathrm{a}}$ \\
\hline & Mouth Drying & $2.83^{\mathrm{d}}$ & $3.56^{\mathrm{c}}$ & $3.92^{\mathrm{bc}}$ & $4.02^{\mathrm{b}}$ & $4.53^{\mathrm{a}}$ \\
\hline & Overall Mouthcoating & $3.28^{\mathrm{e}}$ & $6.01^{\mathrm{d}}$ & $7.56^{\mathrm{c}}$ & $9.12^{\mathrm{b}}$ & $10.50^{\mathrm{a}}$ \\
\hline \multirow[t]{13}{*}{ Flavor } & Overall grain & $5.97^{\mathrm{b}}$ & $7.04^{\mathrm{a}}$ & $7.08^{\mathrm{a}}$ & $7.07^{\mathrm{a}}$ & $7.14^{\mathrm{a}}$ \\
\hline & Sorghum & $4.75^{\mathrm{b}}$ & $5.27^{\mathrm{a}}$ & $5.31^{\mathrm{a}}$ & $5.42^{\mathrm{a}}$ & $5.33^{\mathrm{a}}$ \\
\hline & Soy & $1.03^{\mathrm{b}}$ & $1.63^{\mathrm{a}}$ & $1.83^{\mathrm{a}}$ & $1.66^{\mathrm{a}}$ & $1.67^{\mathrm{a}}$ \\
\hline & Musty & $4.72^{\mathrm{c}}$ & $4.96^{\mathrm{bc}}$ & $5.22^{\mathrm{ab}}$ & $5.29^{\mathrm{ab}}$ & $5.58^{\mathrm{a}}$ \\
\hline & Starch & $7.97^{\mathrm{d}}$ & $8.98^{\mathrm{c}}$ & $9.89^{\mathrm{b}}$ & $10.21^{\mathrm{b}}$ & $11.56^{\mathrm{a}}$ \\
\hline & Toasted & $1.92^{\mathrm{c}}$ & $2.29^{\mathrm{ab}}$ & $2.28^{\mathrm{b}}$ & $2.51^{\mathrm{ab}}$ & $2.56^{\mathrm{a}}$ \\
\hline & Brown & 1.58 & 1.94 & 2.03 & 2.06 & 2.19 \\
\hline & Overall Fruity & 0.00 & 0.00 & 0.00 & 0.00 & 0.00 \\
\hline & Banana & 0.00 & 0.00 & 0.00 & 0.00 & 0.00 \\
\hline & Sweet & 0.42 & 0.21 & 0.42 & 0.17 & 0.36 \\
\hline & Bitter & $3.50^{\mathrm{b}}$ & $4.04^{\mathrm{a}}$ & $4.00^{\mathrm{a}}$ & $3.95^{\mathrm{a}}$ & $3.97^{\mathrm{a}}$ \\
\hline & Sour & 1.94 & 1.96 & 1.97 & 1.90 & 2.14 \\
\hline & Astringent & $2.83^{\mathrm{c}}$ & $3.49^{\mathrm{b}}$ & $3.75^{\mathrm{b}}$ & $3.69^{\mathrm{b}}$ & $4.39^{\mathrm{a}}$ \\
\hline \multirow[t]{5}{*}{ Amplitude } & Impact & $2.44^{\mathrm{b}}$ & $2.78^{\mathrm{a}}$ & $3.03^{\mathrm{a}}$ & $2.96^{\mathrm{a}}$ & $2.75^{\mathrm{a}}$ \\
\hline & Blendedness & 11.00 & 10.87 & 10.94 & 10.89 & 10.92 \\
\hline & Fullness & $2.28^{\mathrm{c}}$ & $2.75^{\mathrm{b}}$ & $3.11^{\mathrm{a}}$ & $2.78^{\mathrm{ab}}$ & $2.94^{\mathrm{ab}}$ \\
\hline & Longevity & $3.16^{\mathrm{b}}$ & $3.39^{\mathrm{ab}}$ & $3.69^{\mathrm{a}}$ & $3.48^{\mathrm{ab}}$ & $3.72^{\mathrm{a}}$ \\
\hline & Overall Amplitude & $2.56^{\mathrm{c}}$ & $2.91^{\mathrm{b}}$ & $3.36^{\mathrm{a}}$ & $3.08^{\mathrm{ab}}$ & $3.14^{\mathrm{ab}}$ \\
\hline
\end{tabular}

$\dagger$ Scores are based on a 0-15-point numeric scale with 0.5 increments.

*Sample with different letters are significantly different from each other in that attribute $(p \leq 0.05)$. 
Table 2-4 Bostwick flow rates ${ }^{\dagger}$ of samples for the study of variations in solid amount."

\begin{tabular}{cc}
\hline solids content $(\% \mathbf{w t} / \mathbf{w t})$ & Flow rate $(\mathbf{c m} . / \mathbf{m i n})$ \\
\hline 10 & $22.33 \pm 0.52^{\mathrm{a}}$ \\
15 & $11.92 \pm 0.29^{\mathrm{b}}$ \\
20 & $5.08 \pm 0.76^{\mathrm{c}}$ \\
25 & $1.75 \pm 0.43^{\mathrm{d}}$ \\
30 & $0.33 \pm 0.14^{\mathrm{e}}$ \\
\hline
\end{tabular}

$\dagger$ Measurements are given as average \pm standard deviation.

*Samples with different letters are significantly different from each other in that attribute $(p \leq 0.05)$.

\section{Added oil content}

The mean scores of the sensory characteristics of cooked porridge with the variations in oil content from $0 \%$ to $40 \%$ of WSSB are shown in Table 2-5. Nine of the 35 sensory attributes were significantly different across samples including toasted aroma, lump size, gumminess, residual particles, grain and bitter flavor, and amplitude attributes. Although these attributes were significantly different, the scores for most significant attributes showed only small (approximately $\leq 0.5$ points on a 15 point scale) differences. The oil added into the porridge might act as a lubricant resulted in the decreasing in size of lumps and gumminess of the products. The addition of oil initially increased the size of lumps (from 0-10\%), but then decreased them (from 20-40\%). The gumminess of the highest oil addition (40\%) was lower by more than 1 point compared to other samples.

Bostwick flow rates of all samples in this study are shown in Table 2-6. Cooked porridges with $30 \%$ and $40 \%$ oil were significantly lower in viscosity although that did not translate into differences in thickness as measured by the sensory panel. The differences in thickness of the products might not be large enough to be detected by trained panelists. Steele $e t$ al. (2014) also mentioned that the perception of increasing viscosity by humans grows about one fifth as fast as the actual viscosity measured by instrument. 
Fleige et al. (2010) reported that replacement of cornmeal with vegetable oil might help reduce viscosity and also could increase the fat content of porridge for infants and children between the age of 6 and 24 months.

Adding oil to children's diets has become a standard recommendation in many developing countries during the complementary feeding period when children are fed thin porridge with a low energy density (Briend, 2005). Therefore, the marginal changes from the additional oil into the product are good in term of product development. Oil can be added to fortified blended foods to increase the energy intake of young children during the complementary feeding without having a major impact on most sensory properties.

Table 2-5 Mean intensity scores $\uparrow$ and separation of sensory attributes of samples for the study of variations in oil content.*

\begin{tabular}{|c|c|c|c|c|c|c|}
\hline & \multirow{2}{*}{ Attribute } & \multicolumn{5}{|c|}{ Oil content (\% of WSSB $)$} \\
\hline & & $\mathbf{0}$ & 10 & 20 & 30 & 40 \\
\hline \multirow[t]{7}{*}{ Aroma } & Grain Overall & 7.08 & 7.06 & 7.16 & 7.28 & 6.72 \\
\hline & Musty Overall & 3.30 & 3.14 & 3.16 & 3.28 & 3.03 \\
\hline & Cardboard & 3.61 & 3.42 & 3.42 & 3.39 & 3.22 \\
\hline & Toasted & $2.39^{\mathrm{b}}$ & $2.31^{\mathrm{b}}$ & $2.38^{\mathrm{b}}$ & $2.72^{\mathrm{a}}$ & $2.39^{\mathrm{b}}$ \\
\hline & Brown & 2.04 & 1.92 & 1.90 & 2.17 & 1.97 \\
\hline & Overall Fruity & 0.00 & 0.00 & 0.00 & 0.00 & 0.00 \\
\hline & Banana & 0.00 & 0.00 & 0.00 & 0.00 & 0.00 \\
\hline \multirow{10}{*}{$\begin{array}{l}\text { Texture/ } \\
\text { Mouthfeel }\end{array}$} & Thickness & 5.48 & 5.64 & 5.79 & 5.50 & 5.00 \\
\hline & Particles & 3.04 & 3.36 & 2.84 & 3.28 & 2.78 \\
\hline & Lumpy (size) & $6.82^{\mathrm{ab}}$ & $8.19^{\mathrm{a}}$ & $7.28^{\mathrm{a}}$ & $4.97^{\mathrm{c}}$ & $5.36^{\mathrm{bc}}$ \\
\hline & Uniformity of size & 8.09 & 6.97 & 7.07 & 6.25 & 7.97 \\
\hline & Adhesiveness & 6.06 & 6.39 & 6.38 & 5.92 & 4.72 \\
\hline & Gumminess & $5.07^{\mathrm{a}}$ & $5.22^{\mathrm{a}}$ & $5.33^{\mathrm{a}}$ & $5.14^{\mathrm{a}}$ & $4.00^{\mathrm{b}}$ \\
\hline & Oily Mouthfeel & 0.86 & 0.86 & 0.68 & 0.97 & 1.08 \\
\hline & Residual particles & $3.12 b^{c}$ & $3.42^{\mathrm{a}}$ & $3.23^{\mathrm{ab}}$ & $3.19^{\mathrm{abc}}$ & $2.92^{\mathrm{c}}$ \\
\hline & Mouth Drying & 3.56 & 3.61 & 3.73 & 3.36 & 3.42 \\
\hline & Overall Mouthcoating & 6.01 & 5.94 & 5.87 & 5.64 & 5.11 \\
\hline
\end{tabular}




\begin{tabular}{|c|c|c|c|c|c|c|}
\hline \multirow[t]{13}{*}{ Flavor } & Overall grain & $7.04^{\mathrm{bc}}$ & $6.83^{\mathrm{bc}}$ & $7.06^{\mathrm{b}}$ & $7.39^{\mathrm{a}}$ & $6.78^{\mathrm{c}}$ \\
\hline & Sorghum & 5.27 & 5.25 & 5.40 & 5.39 & 5.00 \\
\hline & Soy & 1.63 & 1.75 & 1.73 & 1.69 & 1.83 \\
\hline & Musty & 4.96 & 5.25 & 5.22 & 5.33 & 5.03 \\
\hline & Starch & 8.98 & 9.25 & 9.20 & 9.03 & 8.78 \\
\hline & Toasted & 2.29 & 2.22 & 2.33 & 2.50 & 2.19 \\
\hline & Brown & 1.94 & 1.86 & 1.98 & 2.03 & 1.83 \\
\hline & Overall Fruity & 0.00 & 0.00 & 0.00 & 0.00 & 0.00 \\
\hline & Banana & 0.00 & 0.00 & 0.00 & 0.00 & 0.00 \\
\hline & Sweet & 0.21 & 0.47 & 0.39 & 0.44 & 0.44 \\
\hline & Bitter & $4.04^{\mathrm{a}}$ & $3.72^{\mathrm{b}}$ & $4.02^{\mathrm{a}}$ & $3.75^{\mathrm{b}}$ & $3.69^{\mathrm{b}}$ \\
\hline & Sour & 1.96 & 1.83 & 1.93 & 2.00 & 1.86 \\
\hline & Astringent & 3.49 & 3.44 & 3.57 & 3.31 & 3.33 \\
\hline \multirow[t]{5}{*}{ Amplitude } & Impact & $2.78^{\mathrm{b}}$ & $2.86^{\mathrm{b}}$ & $2.74^{\mathrm{b}}$ & $3.06^{\mathrm{a}}$ & $2.81^{\mathrm{b}}$ \\
\hline & Blendedness & 10.87 & 10.69 & 10.72 & 11.14 & 11.11 \\
\hline & Fullness & $2.75^{\mathrm{b}}$ & $2.86^{\mathrm{ab}}$ & $2.73^{\mathrm{b}}$ & $3.11^{\mathrm{a}}$ & $2.86^{\mathrm{ab}}$ \\
\hline & Longevity & 3.39 & 3.42 & 3.35 & 3.50 & 3.25 \\
\hline & Overall Amplitude & $2.91^{\mathrm{b}}$ & $3.08^{\mathrm{ab}}$ & $2.98^{\mathrm{b}}$ & $3.28^{\mathrm{a}}$ & $3.00^{\mathrm{b}}$ \\
\hline
\end{tabular}

$\dagger$ Scores are based on a 0-15-point numeric scale with 0.5 increments.

*Sample with different letters are significantly different from each other in that attribute $(p \leq 0.05)$

Table 2-6 Bostwick flow rates ${ }^{\dagger}$ of samples for the study of variations in oil.*

\begin{tabular}{cc}
\hline Oil content $(\%$ of WSSB) & Flow rate $(\mathbf{c m} . / \mathbf{m i n})$ \\
\hline 0 & $11.92 \pm 0.29^{\mathrm{b}}$ \\
20 & $12.75 \pm 0.75^{\mathrm{b}}$ \\
30 & $12.67 \pm 1.15^{\mathrm{b}}$ \\
40 & $14.50 \pm 0.66^{\mathrm{a}}$ \\
\hline
\end{tabular}

$\dagger$ Measurements are given as average \pm standard deviation.

*Samples with different letters are significantly different from each other in that attribute $(p \leq 0.05)$.

\section{Addition of fruit}

The impact of variations in fruit content on sensory properties is shown in Table 2-7.

Most (21 of 35) sensory attributes were significantly different across samples $(p \leq 0.05)$. While the differences in texture were small, the addition of banana had a major impact on aroma, flavor and amplitude, as was expected. The Bostwick flow rates (Table 2-8) also confirmed that addition of fruit did not change the viscosity of the products. Ripe banana has 3 main chemical 
compositions which are approximately $74.24 \%$ of moisture/water, $16.67 \%$ of sugar and $4.09 \%$ of starch (Tapre \& Jain, 2012). The compositions in ripe banana might balance itself and that resulted in only marginal change in texture of the products.

The addition of fruit reduced the intensity of grain, sorghum, soy and bitter flavor but increased fruit and sweet flavors and also increased the addition of banana to the porridge, influenced the flavor and aroma of banana to be dominant and the perception of the grain characteristics of the products were decreased.

The addition of fruit made the porridge more complex, which resulted in the increase in fruit flavor and amplitude characteristics especially impact, fullness and overall amplitude attributes. This could be positive in relation to palatability. Development of products from the combination of cereal with fruits and vegetables is being used in a number of products. Webb et al. (2011) suggested adding flavor enhancers to formulations of FBFs in order to enhance taste and acceptability which could increase the consumption among sick and undernourished children. A study by Gandhi \& Singh (2014) also stated that porridge with fruit added was highly acceptable by consumers. Moreover, adding fruits or vegetables not only improves the flavor of the products, but also could supplement the vitamins, antioxidants, fiber and phytochemicals in the products (Gandhi \& Singh, 2014; WFP, 2002). 
Table 2-7 Mean intensity scores $\dagger$ and separation of sensory attributes of samples for the study of variations in fruit content.*

\begin{tabular}{|c|c|c|c|c|c|c|}
\hline & \multirow[t]{2}{*}{ Attribute } & \multicolumn{5}{|c|}{ Fruit content(Banana) (\% of WSSB $)$} \\
\hline & & $\mathbf{0}$ & 10 & 20 & 30 & 40 \\
\hline \multirow[t]{7}{*}{ Aroma } & Grain Overall & $7.08^{\mathrm{a}}$ & $5.25^{\mathrm{b}}$ & $4.33^{\mathrm{c}}$ & $4.64^{\mathrm{c}}$ & $4.67^{\mathrm{c}}$ \\
\hline & Musty Overall & $3.30^{\mathrm{a}}$ & $2.69^{\mathrm{b}}$ & $2.64^{\mathrm{b}}$ & $2.53^{\mathrm{b}}$ & $2.81^{\mathrm{b}}$ \\
\hline & Cardboard & $3.61^{\mathrm{a}}$ & $2.61^{\mathrm{b}}$ & $2.42 b^{c}$ & $2.17^{\mathrm{c}}$ & $2.69^{\mathrm{b}}$ \\
\hline & Toasted & $2.39^{\mathrm{a}}$ & $2.00^{\mathrm{b}}$ & $1.86^{\mathrm{b}}$ & $1.89^{\mathrm{b}}$ & $2.08^{\mathrm{ab}}$ \\
\hline & Brown & 2.04 & 1.75 & 1.81 & 1.83 & 1.86 \\
\hline & Overall Fruity & $0.00^{\mathrm{d}}$ & $2.42^{\mathrm{c}}$ & $3.33^{\mathrm{b}}$ & $4.28^{\mathrm{a}}$ & $4.31^{\mathrm{a}}$ \\
\hline & Banana & $0.00^{\mathrm{d}}$ & $2.33^{\mathrm{c}}$ & $3.33^{\mathrm{b}}$ & $4.17^{\mathrm{a}}$ & $4.31^{\mathrm{a}}$ \\
\hline \multirow{10}{*}{$\begin{array}{l}\text { Texture/ } \\
\text { Mouthfeel }\end{array}$} & Thickness & 5.48 & 5.53 & 5.67 & 5.75 & 5.94 \\
\hline & Particles & 3.04 & 3.00 & 3.25 & 3.17 & 3.39 \\
\hline & Lumpy (size) & 6.82 & 7.42 & 7.83 & 7.94 & 9.22 \\
\hline & Uniformity of size & $8.09^{\mathrm{a}}$ & $6.34^{\mathrm{b}}$ & $5.47^{\mathrm{c}}$ & $6.14^{\mathrm{bc}}$ & $5.81^{\mathrm{bc}}$ \\
\hline & Adhesiveness & 6.06 & 5.31 & 6.28 & 6.14 & 6.17 \\
\hline & Gumminess & 5.07 & 4.78 & 4.97 & 4.97 & 5.22 \\
\hline & Oily Mouthfeel & $0.86^{\mathrm{b}}$ & $1.25^{\mathrm{a}}$ & $1.36^{\mathrm{a}}$ & $1.19^{\mathrm{a}}$ & $1.14^{\mathrm{ab}}$ \\
\hline & Residual particles & 3.12 & 3.25 & 3.33 & 3.36 & 3.56 \\
\hline & Mouth Drying & 3.56 & 3.50 & 3.50 & 3.53 & 3.92 \\
\hline & Overall Mouthcoating & 6.01 & 6.00 & 5.94 & 5.47 & 5.72 \\
\hline \multirow[t]{13}{*}{ Flavor } & Overall grain & $7.04^{\mathrm{a}}$ & $5.53^{\mathrm{b}}$ & $5.14^{\mathrm{b}}$ & $5.19^{\mathrm{b}}$ & $5.28^{\mathrm{b}}$ \\
\hline & Sorghum & $5.27^{\mathrm{a}}$ & $4.50^{\mathrm{b}}$ & $4.50^{\mathrm{b}}$ & $4.28^{\mathrm{b}}$ & $4.47^{\mathrm{b}}$ \\
\hline & Soy & $1.63^{\mathrm{a}}$ & $1.44^{\mathrm{ab}}$ & $1.22^{\mathrm{b}}$ & $1.36 \mathrm{a}^{\mathrm{b}}$ & $1.31^{\mathrm{b}}$ \\
\hline & Musty & 4.96 & 5.14 & 5.28 & 5.33 & 5.31 \\
\hline & Starch & 8.98 & 8.89 & 9.00 & 8.72 & 8.86 \\
\hline & Toasted & 2.29 & 2.14 & 2.31 & 2.14 & 2.25 \\
\hline & Brown & 1.94 & 1.97 & 1.92 & 2.00 & 2.03 \\
\hline & Overall Fruity & $0.00^{\mathrm{d}}$ & $2.14^{\mathrm{c}}$ & $3.22^{\mathrm{b}}$ & $3.92^{\mathrm{a}}$ & $4.00^{\mathrm{a}}$ \\
\hline & Banana & $0.00^{\mathrm{d}}$ & $2.08^{c}$ & $3.19^{\mathrm{b}}$ & $3.81^{\mathrm{a}}$ & $3.97^{\mathrm{a}}$ \\
\hline & Sweet & $0.21^{\mathrm{d}}$ & $1.39^{\mathrm{c}}$ & $1.78^{\mathrm{b}}$ & $2.11^{\mathrm{a}}$ & $2.06^{\mathrm{ab}}$ \\
\hline & Bitter & $4.04^{\mathrm{a}}$ & $3.72^{\mathrm{b}}$ & $3.58^{\mathrm{b}}$ & $3.69^{\mathrm{b}}$ & $3.86^{\mathrm{ab}}$ \\
\hline & Sour & $1.96^{\mathrm{c}}$ & $2.06^{\mathrm{bc}}$ & $2.06^{\mathrm{bc}}$ & $2.31^{\mathrm{a}}$ & $2.22^{\mathrm{ab}}$ \\
\hline & Astringent & 3.49 & 3.39 & 3.36 & 3.50 & 3.61 \\
\hline \multirow[t]{5}{*}{ Amplitude } & Impact & $2.78^{\mathrm{c}}$ & $4.11^{\mathrm{b}}$ & $4.44^{\mathrm{b}}$ & $4.94^{\mathrm{a}}$ & $4.97^{\mathrm{a}}$ \\
\hline & Blendedness & $10.87^{\mathrm{a}}$ & $9.72^{\mathrm{b}}$ & $9.03^{\mathrm{c}}$ & $9.00^{c}$ & $9.11^{\mathrm{c}}$ \\
\hline & Fullness & $2.75^{\mathrm{c}}$ & $4.19^{\mathrm{b}}$ & $4.78^{\mathrm{a}}$ & $4.92^{\mathrm{a}}$ & $5.19^{\mathrm{a}}$ \\
\hline & Longevity & $3.39^{\mathrm{d}}$ & $4.67^{\mathrm{c}}$ & $5.08^{\mathrm{b}}$ & $5.42^{\mathrm{a}}$ & $5.33^{\mathrm{ab}}$ \\
\hline & Overall Amplitude & $2.91^{\mathrm{c}}$ & $4.28^{\mathrm{b}}$ & $4.86^{\mathrm{a}}$ & $5.19^{\mathrm{a}}$ & $5.22^{\mathrm{a}}$ \\
\hline
\end{tabular}

$\uparrow$ Scores are based on a 0-15-point numeric scale with 0.5 increments.

*Sample with different letters are significantly different from each other in that attribute $(\mathrm{p} \leq 0.05)$ 
Table 2-8 Bostwick flow rates ${ }^{\dagger}$ of samples for the study of variations in fruit content.

\begin{tabular}{cc}
\hline Fruit content(Banana) $(\%$ of WSSB) & Flow rate $(\mathbf{c m} . \mathbf{m i n})$ \\
\hline 0 & $11.92 \pm 0.29$ \\
10 & $12.00 \pm 0.66$ \\
20 & $11.67 \pm 0.29$ \\
30 & $12.00 \pm 0.75$ \\
40 & $12.58 \pm 0.29$ \\
\hline
\end{tabular}

$\dagger$ Measurements are given as average \pm standard deviation.

\section{Cooking time}

The variations in cooking time resulted in small changes in aroma, flavor, and amplitude. Larger changes were found in some textural characteristics. Table 2-9 showed the intensity scores of each attributes of cooked porridges with different cooking times. Although there were 14 attributes that were significantly different among samples $(p \leq 0.05)$, only texture attributes had large differences. As expected, increasing cooking time resulted in a thicker porridge. The adhesiveness, gumminess and lump size of porridge also increased when porridge cooked for a longer time. Porridge in this study prepared from extruded FBFs, which starch granules were already gelatinized. Therefore, the gelatinization of starch granules during cooking did not have a big impact on thickness of the product. The main reason for a thicker porridge in this study was more water cooked out of the product. The longer time porridge is cooked, the higher the amount of water evaporated from the product and result in a pasty, gummy product.

The results of Bostwick flow rate tests (Table 2-10) showed that the thickness of the porridge increased when the cooking time of the product increased. This result agreed with the sensory results. Bostwick flow rate can be used as an indication of sensory perception in porridge (Mouquet et al. 2006) especially texture characteristics, although we did not find that for all the studies in this research.

Although the FBF product used for cooking the porridge in this study was an extruded product and does not need additional cooking, it still is advisable to cook the product before 
consumption because of the poor water quality in many areas that this product will be distributed. The boiling of water is still important to prevent the contamination and foodborne illnesses (Fleige et al., 2010).

Table 2-9 Mean intensity scores $\uparrow$ and separation of sensory attributes of samples for the study of variations in cooking time.*

\begin{tabular}{|c|c|c|c|c|c|c|}
\hline & \multirow{2}{*}{ Attribute } & \multicolumn{5}{|c|}{ Cooking time (min.) } \\
\hline & & 2 & 5 & 10 & 20 & 30 \\
\hline \multirow[t]{7}{*}{ Aroma } & Grain Overall & 6.89 & 7.08 & 7.12 & 7.17 & 7.08 \\
\hline & Musty Overall & 3.22 & 3.30 & 3.17 & 3.39 & 3.31 \\
\hline & Cardboard & $3.31^{\mathrm{b}}$ & $3.61^{\mathrm{a}}$ & $3.32^{\mathrm{b}}$ & $3.39^{\mathrm{ab}}$ & $3.58^{\mathrm{a}}$ \\
\hline & Toasted & 2.25 & 2.39 & 2.33 & 2.50 & 2.39 \\
\hline & Brown & 1.86 & 2.04 & 2.03 & 2.08 & 2.00 \\
\hline & Overall Fruity & 0.00 & 0.00 & 0.00 & 0.00 & 0.00 \\
\hline & Banana & 0.00 & 0.00 & 0.00 & 0.00 & 0.00 \\
\hline \multirow{10}{*}{$\begin{array}{l}\text { Texture/ } \\
\text { Mouthfeel }\end{array}$} & Thickness & $4.94^{\mathrm{c}}$ & $5.48^{\mathrm{c}}$ & $6.49^{c}$ & $7.25^{\mathrm{b}}$ & $8.44^{\mathrm{a}}$ \\
\hline & Particles & 3.28 & 3.04 & 3.29 & 3.50 & 3.81 \\
\hline & Lumpy (size) & $5.56^{\mathrm{c}}$ & $6.82 b^{c}$ & $5.85^{\mathrm{c}}$ & $8.33^{\mathrm{ab}}$ & $9.00^{\mathrm{a}}$ \\
\hline & Uniformity of size & $8.42^{\mathrm{a}}$ & $8.09^{\mathrm{a}}$ & $8.07^{\mathrm{a}}$ & $7.36^{\mathrm{a}}$ & $5.97^{\mathrm{b}}$ \\
\hline & Adhesiveness & $4.78^{\mathrm{d}}$ & $6.06^{\mathrm{d}}$ & $7.08^{\mathrm{c}}$ & $7.47^{\mathrm{b}}$ & $9.14^{\mathrm{a}}$ \\
\hline & Gumminess & $4.19^{\mathrm{d}}$ & $5.07^{\mathrm{cd}}$ & $5.94^{\mathrm{bc}}$ & $6.37^{\mathrm{b}}$ & $7.56^{\mathrm{a}}$ \\
\hline & Oily Mouthfeel & 0.72 & 0.86 & 0.84 & 0.67 & 0.72 \\
\hline & Residual particles & $3.14^{\mathrm{b}}$ & $3.12^{\mathrm{b}}$ & $3.53^{\mathrm{ab}}$ & $3.47^{\mathrm{ab}}$ & $3.69^{\mathrm{a}}$ \\
\hline & Mouth Drying & 3.58 & 3.56 & 3.72 & 3.69 & 3.75 \\
\hline & Overall Mouthcoating & $4.89^{c}$ & $6.01^{\mathrm{b}}$ & $6.26^{\mathrm{b}}$ & $6.53^{\mathrm{b}}$ & $7.78^{\mathrm{a}}$ \\
\hline \multirow[t]{13}{*}{ Flavor } & Overall grain & $6.75^{\mathrm{b}}$ & $7.04^{\mathrm{ab}}$ & $6.97^{\mathrm{ab}}$ & $7.28^{\mathrm{ab}}$ & $7.00^{\mathrm{ab}}$ \\
\hline & Sorghum & 5.11 & 5.27 & 5.11 & 5.42 & 5.47 \\
\hline & Soy & 1.53 & 1.63 & 1.60 & 1.83 & 1.83 \\
\hline & Musty & $5.00^{\mathrm{b}}$ & $4.96^{\mathrm{b}}$ & $5.28^{\mathrm{ab}}$ & $5.22^{\mathrm{a} b}$ & $5.47^{\mathrm{a}}$ \\
\hline & Starch & $8.83^{\mathrm{b}}$ & $8.98 b$ & $9.22^{\mathrm{b}}$ & $9.14^{\mathrm{b}}$ & $9.94^{\mathrm{a}}$ \\
\hline & Toasted & $2.22^{\mathrm{b}}$ & $2.29^{\mathrm{ab}}$ & $2.19^{\mathrm{b}}$ & $2.44^{\mathrm{ab}}$ & $2.56^{\mathrm{a}}$ \\
\hline & Brown & 1.89 & 1.94 & 1.89 & 1.97 & 2.11 \\
\hline & Overall Fruity & 0.00 & 0.00 & 0.00 & 0.00 & 0.00 \\
\hline & Banana & 0.00 & 0.00 & 0.00 & 0.00 & 0.00 \\
\hline & Sweet & $0.25^{\mathrm{bc}}$ & $0.21^{\mathrm{c}}$ & $0.36^{\mathrm{abc}}$ & $0.47^{\mathrm{ab}}$ & $0.53^{\mathrm{a}}$ \\
\hline & Bitter & 3.92 & 4.04 & 4.04 & 4.00 & 4.08 \\
\hline & Sour & 1.83 & 1.96 & 2.12 & 2.11 & 2.03 \\
\hline & Astringent & 3.53 & 3.49 & 3.69 & 3.67 & 3.72 \\
\hline
\end{tabular}




\begin{tabular}{llccccc} 
Amplitude & Impact & 2.75 & 2.78 & 2.97 & 2.81 & 3.00 \\
& Blendedness & 10.94 & 10.87 & 11.01 & 11.06 & 10.69 \\
& Fullness & 2.69 & 2.75 & 2.93 & 2.83 & 2.92 \\
& Longevity & 3.33 & 3.39 & 3.43 & 3.42 & 3.64 \\
& Overall Amplitude & $3.00^{\mathrm{bc}}$ & $2.91^{\mathrm{c}}$ & $3.18^{\mathrm{ab}}$ & $3.00^{\mathrm{bc}}$ & $3.28^{\mathrm{a}}$ \\
\hline
\end{tabular}

$\dagger$ Scores are based on a 0-15-point numeric scale with 0.5 increments.

*Sample with different letters are significantly different from each other in that attribute $(p \leq 0.05)$.

Table 2-10 Bostwick flow rates ${ }^{\dagger}$ of samples for the study of variations in cooking time.*

\begin{tabular}{cc}
\hline Cooking time (min.) & Flow rate $(\mathbf{c m} . / \mathbf{m i n})$ \\
\hline 2 & $14.17 \pm 0.52^{\mathrm{a}}$ \\
5 & $11.92 \pm 0.29^{\mathrm{b}}$ \\
10 & $9.58 \pm 1.61^{\mathrm{c}}$ \\
20 & $7.08 \pm 0.76^{\mathrm{d}}$ \\
\hline
\end{tabular}

$\dagger$ Measurements are given as average \pm standard deviation.

*Samples with different letters are significantly different from each other in that attribute $(p \leq 0.05)$.

\section{Serving temperature/Holding time}

Only 2 attributes $(p \leq 0.05)$ differentiated the treatments in the serving temperature/holding time study: cardboard aroma and residual particles of the product (Table 211) and those differences were marginal. The results from the Boswick flow rate (Table 2-12) supported the sensory study results for no differences in thickness. This might be due to the nature of extruded products. The extrusion of starchy foods partially or completely destroyed crystalline structure of starch granules (Hagenimana et al., 2006). Therefore, there were only small amount of retrogradation occurred during cooling procedure and resulted in small changes in product consistency.

This result means that cooked porridges from whole sorghum soy blend had a high tolerance to serving temperature or holding time. While the suggested serving temperature of porridge for adults was $70^{\circ} \mathrm{C}$ (Rowe et al., 2009), the suggested serving temperature for infant was $45^{\circ} \mathrm{C}$ (Mouquet et al., 2006). The adults and young children or infants should have almost 
the same sensory perception of the porridge, even if they consumed the porridge at the different serving temperature. This is a positive finding because it means that mothers and infants are experiencing similar flavors, even when they are eating it at different temperatures. Thus, consumer testing with infant foods by using mothers or caregivers as surrogates may be possible even if the serving temperature is different. The data collected from mothers or caregivers could be a good representative for their children's perception on the product.

Additionally, a preliminary field study in Tanzania showed that mothers would cook the porridge for their children only once per day in the morning. Caregivers fed the porridge to their children in the morning and the leftover porridge was kept in thermo pot to keep the porridge warm; the same porridge was given to the children again in the afternoon. Because of the tolerance to serving temperature/holding time children should get a similar sensory perception of the porridge fed at different times of the day even when the porridge is prepared only once.

Table 2-11 Mean intensity scores $\uparrow$ and separation of sensory attributes of samples for the study of variations in serving temperature.*

\begin{tabular}{llccc}
\hline & & \multicolumn{3}{c}{ Serving temperature $\left.\mathbf{(}^{\circ} \mathbf{C}\right)$} \\
\cline { 2 - 4 } Attribute & $\mathbf{3 0}$ & $\mathbf{4 5}$ & $\mathbf{7 0}$ \\
\hline Aroma & Grain Overall & 7.06 & 7.08 & 7.00 \\
& Musty Overall & 3.36 & 3.30 & 3.25 \\
& Cardboard & $3.39^{\mathrm{ab}}$ & $3.61^{\mathrm{a}}$ & $3.25^{\mathrm{b}}$ \\
& Toasted & 2.28 & 2.39 & 2.53 \\
& Brown & 1.94 & 2.04 & 2.00 \\
& Overall Fruity & 0.00 & 0.00 & 0.00 \\
Moxture/ & Banana & 0.00 & 0.00 & 0.00 \\
& Thickness & 5.39 & 5.48 & 5.19 \\
& Particles & 3.17 & 3.04 & 2.81 \\
& Lumpy (size) & 6.28 & 6.82 & 5.61 \\
& Uniformity of size & 8.03 & 8.09 & 8.19 \\
& Adhesiveness & 5.92 & 6.06 & 4.81 \\
& Gumminess & 5.28 & 5.07 & 4.56 \\
& Oily Mouthfeel & 0.83 & 0.86 & 0.81
\end{tabular}




\begin{tabular}{llccc} 
& Residual particles & $3.44^{\mathrm{a}}$ & $3.11^{\mathrm{ab}}$ & $3.06^{\mathrm{b}}$ \\
\multirow{5}{*}{ Flavor } & 3.78 & 3.56 & 3.47 \\
& Mouth Drying & 5.69 & 6.01 & 5.69 \\
& Overall Mouthcoating & 6.89 & 7.04 & 6.81 \\
& Overall grain & 5.11 & 5.27 & 5.08 \\
& Sorghum & 1.58 & 1.63 & 5.33 \\
& Soy & 5.11 & 4.96 & 9.06 \\
& Musty & 8.97 & 8.98 & 2.31 \\
& Starch & 2.11 & 2.03 \\
& Toasted & 1.81 & 0.00 \\
& Brown & 0.00 & 1.94 & 0.00 \\
& Overall Fruity & 0.00 & 0.33 \\
& Banana & 0.00 & 0.00 & 3.92 \\
& Sweet & 0.21 & 1.94 \\
& Bitter & 0.28 & 4.04 & 3.28 \\
& Sour & 3.92 & 1.96 & 2.92 \\
& Astringent & 2.08 & 3.49 & 11.06 \\
& Impact & 3.67 & 2.78 & 2.75 \\
& Blendedness & 10.87 & 3.31 \\
& Fullness & 2.75 & 3.06 \\
\hline Longevity & 10.94 & 3.39 &
\end{tabular}

$\dagger$ Scores are based on a 0-15-point numeric scale with 0.5 increments.

$*$ Sample with different letters are significantly different from each other in that attribute $(p \leq 0.05)$.

Table 2-12 Bostwick flow rates ${ }^{\dagger}$ of samples for the study of variations in serving temperature.

\begin{tabular}{cc}
\hline Serving temperature $\left({ }^{\circ} \mathbf{C}\right)$ & Flow rate $(\mathbf{c m} . / \mathbf{m i n})$ \\
\hline 30 & $11.42 \pm 0.38$ \\
45 & $11.92 \pm 0.29$ \\
70 & $13.50 \pm 0.87$ \\
\hline
\end{tabular}

$\dagger$ Measurements are given as average \pm standard deviation. 


\section{Conclusion}

The tolerance testing showed that porridge prepared from WSSB had generally had high tolerance to variations in ingredients and cooking procedures. A number of small differences were found in most sensory properties, but large differences in sensory properties occurred only in areas that were expected such as in thickness and adhesiveness when solids content varied or in sweetness and fruit flavor when fruit was added. The high tolerance in ingredient or procedure variations of WSSB bodes well for product development because it means that the product can be modified during preparation by consumers without having a major impact on most sensory properties.

\section{Acknowledgments}

The authors specially thank Dr. Lijia Zhu who provided sample for this study. We also thank the staffs of the Sensory Analysis Center who assisted in conducting the study.

\section{References}

Adeyemi, O., Oladiji, A. (2009). Compositional changes in banana (musa ssp.) fruits during ripening. African Journal of Biotechnology, 8(5)

Anglani, C. (1998). Sorghum for human food - A review. Plant Foods for Human Nutrition, 52(1), 85-95. doi:10.1023/A:1008065519820

Briend, A. (2005). Should we add oil to complementary foods for breastfed children in developing countries? Journal of Pediatric Gastroenterology and Nutrition; J.Pediatr.Gastroenterol.Nutr., 41(1), 12-13.

de Pee, S., Bloem, M. W. (2009). Current and potential role of specially formulated foods and food supplements for preventing malnutrition among 6-to 23-month-old children and for treating moderate malnutrition among 6-to 59-month-old children. Food \& Nutrition Bulletin, 30(3), 434-463. 
Fleige, L. E., Moore, W. R., Garlick, P. J., Murphy, S. P., Turner, E. H., Dunn, M. L., . . . Schaefer, S. E. (2010). Recommendations for optimization of fortified and blended food aid products from the united states. Nutrition Reviews, 68(5), 290-315.

Gandhi, N., Singh, B. (2014). Study of extrusion behaviour and porridge making characteristics of wheat and guava blends. Journal of Food Science and Technology,51(3), 1-7.

Garcia, J.M., Chambers, E.IV., Clark, M., Helverson, J., Matta, Z. (2010). Quality of care issues for dysphagia: modifications involving oral fluids. Journal of Clinical Nursing, 19(11-12), 1618-1624.

Hagenimana, A., Ding, X., Fang, T. (2006). Evaluation of rice flour modified by extrusion cooking. Journal of Cereal Science, 43(1), 38-46.

Levis, P.A, Chambers, E. IV, Chambers, D.H., and Hollingsworth, M.G. (1996). Consumer use of package directions for familiar and unfamiliar products. In. Gelinas, A.D. (Ed.) "Sensory techniques used in conducting packaging research with consumers" STP 1316, ASTM, West Conshohocken, PA pp 16-24

Mouquet, C., Greffeuille, V., Treche, S. (2006). Characterization of the consistency of gruels consumed by infants in developing countries: Assessment of the bostwick consistometer and comparison with viscosity measurements and sensory perception. International Journal of Food Sciences and Nutrition, 57(7-8), 459-469. doi:10.1080/09637480600931618

Moussa, M., Qin, X., Chen, L. F., Campanella, O. H., Hamaker, B. R. (2011). High- quality instant sorghum porridge flours for the west african market using continuous processor cooking. International Journal of Food Science and Technology, 46(11), 2344-2350. doi:10.1111/j.1365-2621.2011.02755.x

North American Millers Association (2014). Porridge and Gruel Recipes. Available online at http://www.namamillers.org/issues/food-aid/food-aid-recipes/world-food-programmerecipes/porridge-and-gruel-recipes/. Accessed 11-20-14.

Pérez-Expósito, A. B., Klein, B. P. (2009). Impact of fortified blended food aid products on nutritional status of infants and young children in developing countries. Nutrition Reviews, 67(12), 706-718.

Rowe, J. P., Ogden, L. V., Pike, O. A., Steele, F. M., Dunn, M. L. (2009). Effect of end- user preparation methods on vitamin content of fortified humanitarian food-aid commodities. Journal of Food Composition and Analysis, 22(1), 33-37. doi:10.1016/j.jfca.2008.09.004

Rowe, J.P., Brodegard, W.C., Pike, O. A., Steele, F. M., Dunn, M. L. (2008). Storage, preparation, and usage of fortified food aid among guatemalan, ugandan, and malawian beneficiaries: A field study report. Food and Nutrition Bulletin, 29(3), 213-220. 
Steele, C. M., James, D. F., Hori, S., Polacco, R. C., Yee, C. (2014). Oral Perceptual Discrimination of Viscosity Differences for Non-Newtonian Liquids in the Nectar-and Honey-Thick Ranges. Dysphagia, 1-10.

Tapre, A. R., Jain, R. K. (2012). Study of advanced maturity stages of banana. Int. J. Adv. Eng. Res. Stud, 1, 272-274.

Tortoe, C., Akonor, P. T., Nketia, S., Owusu, M., Glover-Amengor, M., Hagen, L., Padi, A. (2014). Assessing the Sensory Characteristics and Consumer Preferences of Yam-CowpeaSoybean Porridge in the Accra Metropolitan Area. International Journal of Nutrition and Food Sciences, 3(2), 127-132.

USDA. (2005). CSB11. Corn soy blends for use in export programs. U.S. Department of Agriculture. Commodity Requirements.

Vieu MC, Traore T, Treche S. (2001). Effects of energy density and sweetness of gruels on Burkinabe infant energy intakes in free living conditions. International Journal of Food Sciences and Nutrition 52,213-218.

Webb P, Rogers B, Rosenberg I, Schlossman N, Wanke C, Bagriansky J, Sadler K, Johnson Q, Tilahun J, Masterson A, Narayan A. (2011). Delivering Improved Nutrition : Recommendations for Changes to U.S.Food Aid Products and Programming. Boston, MA: Tufts University.

World Food Programme. (2002). Fortified Blended Foods: Recipes, Facts and Practical Uses. Pp. 58.

Wood, J., M. Palazzo, and P. Dijkhuizen. (2008). Fortified Blended Foods: From a Nutritional Objective to a Development Opportunity. The Contribution of WFP to the Production and Use of Blended Foods in Developing Countries. Report to WFP. Rome. Mimeo (original date 2006; revised June 2008). 


\title{
Appendix A - Ballot for porridge descriptive analysis
}

\author{
Panelist: \\ Sample code: \\ Date \\ $\underline{\text { AROMA }}$ \\ Grain, Overall \\ $\begin{array}{lllllllllllllllllllllllllllllll}0 & 0.5 & 1 & 1.5 & 2 & 2.5 & 3 & 3.5 & 4 & 4.5 & 5 & 5.5 & 6 & 6.5 & 7 & 7.5 & 8 & 8.5 & 9 & 9.5 & 10 & 10.5 & 11 & 11.5 & 12 & 12.5 & 13 & 13.5 & 14 & 14.5 & 15\end{array}$ \\ Musty Overall \\ $\begin{array}{lllllllllllllllllllllllllllllll}0 & 0.5 & 1 & 1.5 & 2 & 2.5 & 3 & 3.5 & 4 & 4.5 & 5 & 5.5 & 6 & 6.5 & 7 & 7.5 & 8 & 8.5 & 9 & 9.5 & 10 & 10.5 & 11 & 11.5 & 12 & 12.5 & 13 & 13.5 & 14 & 14.5 & 15\end{array}$ \\ Cardboard \\ $\begin{array}{lllllllllllllllllllllllllllllll}0 & 0.5 & 1 & 1.5 & 2 & 2.5 & 3 & 3.5 & 4 & 4.5 & 5 & 5.5 & 6 & 6.5 & 7 & 7.5 & 8 & 8.5 & 9 & 9.5 & 10 & 10.5 & 11 & 11.5 & 12 & 12.5 & 13 & 13.5 & 14 & 14.5 & 15\end{array}$ \\ Toasted \\ $\begin{array}{lllllllllllllllllllllllllllllll}0 & 0.5 & 1 & 1.5 & 2 & 2.5 & 3 & 3.5 & 4 & 4.5 & 5 & 5.5 & 6 & 6.5 & 7 & 7.5 & 8 & 8.5 & 9 & 9.5 & 10 & 10.5 & 11 & 11.5 & 12 & 12.5 & 13 & 13.5 & 14 & 14.5 & 15\end{array}$ \\ Brown \\ $\begin{array}{lllllllllllllllllllllllllllllll}0 & 0.5 & 1 & 1.5 & 2 & 2.5 & 3 & 3.5 & 4 & 4.5 & 5 & 5.5 & \mathbf{6} & 6.5 & 7 & 7.5 & 8 & 8.5 & 9 & 9.5 & 10 & 10.5 & 11 & 11.5 & 12 & 12.5 & 13 & 13.5 & 14 & 14.5 & 15\end{array}$ \\ Overall Fruity \\ $\begin{array}{lllllllllllllllllllllllllllllll}0 & 0.5 & 1 & 1.5 & 2 & 2.5 & 3 & 3.5 & 4 & 4.5 & 5 & 5.5 & 6 & 6.5 & 7 & 7.5 & 8 & 8.5 & 9 & 9.5 & 10 & 10.5 & 11 & 11.5 & 12 & 12.5 & 13 & 13.5 & 14 & 14.5 & 15\end{array}$ \\ Banana \\ $\begin{array}{lllllllllllllllllllllllllllllll}0 & 0.5 & 1 & 1.5 & 2 & 2.5 & 3 & 3.5 & 4 & 4.5 & 5 & 5.5 & \mathbf{6} & 6.5 & 7 & 7.5 & 8 & 8.5 & 9 & 9.5 & 10 & 10.5 & 11 & 11.5 & \mathbf{1 2} & 12.5 & 13 & 13.5 & 14 & 14.5 & 15\end{array}$ \\ $\begin{array}{lllllllllllllllllllllllllllllll}0 & 0.5 & 1 & 1.5 & 2 & 2.5 & 3 & 3.5 & 4 & 4.5 & 5 & 5.5 & 6 & 6.5 & 7 & 7.5 & 8 & 8.5 & 9 & 9.5 & 10 & 10.5 & 11 & 11.5 & 12 & 12.5 & 13 & 13.5 & 14 & 14.5 & 15\end{array}$ \\ $\begin{array}{lllllllllllllllllllllllllllllll}0 & 0.5 & 1 & 1.5 & 2 & 2.5 & 3 & 3.5 & 4 & 4.5 & 5 & 5.5 & 6 & 6.5 & 7 & 7.5 & 8 & 8.5 & 9 & 9.5 & 10 & 10.5 & 11 & 11.5 & 12 & 12.5 & 13 & 13.5 & 14 & 14.5 & 15\end{array}$
}

\section{TEXTURE/MOUTHFEEL}

Thickness/

Viscosity

$\begin{array}{lllllllllllllllllllllllllllllll}0 & 0.5 & 1 & 1.5 & 2 & 2.5 & 3 & 3.5 & 4 & 4.5 & 5 & 5.5 & 6 & 6.5 & \mathbf{7} & 7.5 & 8 & 8.5 & 9 & 9.5 & 10 & 10.5 & 11 & 11.5 & 12 & 12.5 & 13 & 13.5 & \mathbf{1 4} & 14.5 & 15\end{array}$

Particles

$\begin{array}{lllllllllllllllllllllllllllllll}0 & 0.5 & 1 & 1.5 & 2 & 2.5 & 3 & 3.5 & 4 & 4.5 & 5 & 5.5 & 6 & 6.5 & 7 & 7.5 & 8 & 8.5 & 9 & 9.5 & 10 & 10.5 & 11 & 11.5 & 12 & 12.5 & 13 & 13.5 & 14 & 14.5 & 15\end{array}$

Lumpy (size)

$\begin{array}{lllllllllllllllllllllllllllllll}0 & 0.5 & 1 & 1.5 & 2 & 2.5 & 3 & 3.5 & 4 & 4.5 & 5 & 5.5 & 6 & 6.5 & 7 & 7.5 & 8 & 8.5 & \mathbf{9} & 9.5 & 10 & 10.5 & 11 & 11.5 & 12 & 12.5 & 13 & 13.5 & 14 & 14.5 & 15\end{array}$

$\begin{array}{llllllllllllllllllllllllllllllll}\text { Uniformity of size: } & 0 & 0.5 & 1 & 1.5 & 2 & 2.5 & 3 & 3.5 & 4 & 4.5 & 5 & 5.5 & 6 & \mathbf{6 . 5} & 7 & 7.5 & 8 & 8.5 & 9 & 9.5 & 10 & 10.5 & 11 & 11.5 & \mathbf{1 2} & 12.5 & 13 & 13.5 & 14 & 14.5 & 15\end{array}$

Adhesiveness

$\begin{array}{lllllllllllllllllllllllllllllll}0 & 0.5 & 1 & 1.5 & 2 & 2.5 & 3 & \mathbf{3 . 5} & 4 & 4.5 & 5 & 5.5 & 6 & 6.5 & 7 & 7.5 & 8 & 8.5 & 9 & 9.5 & \mathbf{1 0} & 10.5 & 11 & 11.5 & 12 & 12.5 & \mathbf{1 3} & 13.5 & 14 & 14.5 & 15\end{array}$

Gumminess

$\begin{array}{lllllllllllllllllllllllllllllll}0 & 0.5 & 1 & 1.5 & 2 & 2.5 & 3 & 3.5 & 4 & 4.5 & 5 & 5.5 & 6 & 6.5 & 7 & 7.5 & 8 & 8.5 & 9 & 9.5 & 10 & 10.5 & 11 & 11.5 & 12 & 12.5 & 13 & 13.5 & 14 & 14.5 & 15\end{array}$

Oily Mouthfeel

$\begin{array}{lllllllllllllllllllllllllllllll}0 & 0.5 & 1 & 1.5 & 2 & 2.5 & 3 & 3.5 & 4 & 4.5 & \mathbf{5} & 5.5 & 6 & 6.5 & 7 & \mathbf{7 . 5} & 8 & 8.5 & 9 & 9.5 & 10 & 10.5 & 11 & 11.5 & 12 & 12.5 & 13 & 13.5 & 14 & 14.5 & 15\end{array}$ 


\section{TEXTURE/MOUTHFEEL After Swallowing}

Residual

Particles

Mouth Drying

Overall

Mouthcoating

\section{FLAVOR}

Overall Grain

Sorghum

Soy

Musty

Starch

Toasted

Brown

Overall Fruity

Banana

Sweet

Bitter

Sour

Astringent

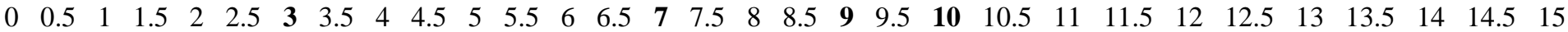

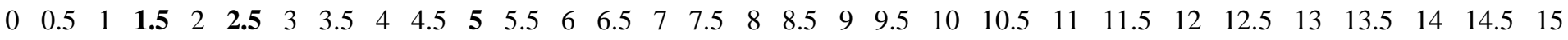

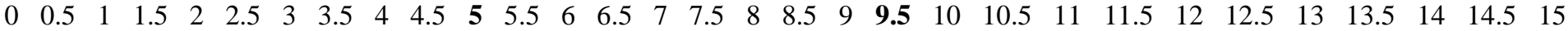

$\begin{array}{llllllllllllllllllllllllllllllll}0 & 0.5 & 1 & 1.5 & 2 & 2.5 & 3 & 3.5 & 4 & 4.5 & 5 & 5.5 & 6 & 6.5 & 7 & 7.5 & \mathbf{8} & 8.5 & 9 & 9.5 & 10 & 10.5 & 11 & 11.5 & 12 & 12.5 & 13 & 13.5 & 14 & 14.5 & 15\end{array}$

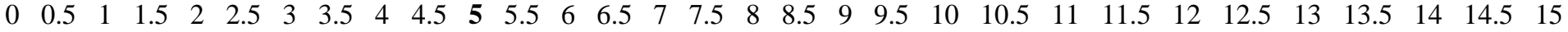
$\begin{array}{lllllllllllllllllllllllllllllll}0 & 0.5 & 1 & 1.5 & 2 & 2.5 & 3 & 3.5 & 4 & 4.5 & 5 & 5.5 & 6 & 6.5 & 7 & 7.5 & 8 & 8.5 & 9 & 9.5 & 10 & 10.5 & 11 & 11.5 & 12 & 12.5 & 13 & 13.5 & 14 & 14.5 & 15\end{array}$ $\begin{array}{lllllllllllllllllllllllllllllll}0 & 0.5 & 1 & 1.5 & 2 & 2.5 & 3 & 3.5 & 4 & 4.5 & 5 & 5.5 & 6 & 6.5 & 7 & 7.5 & 8 & 8.5 & 9 & 9.5 & 10 & 10.5 & 11 & 11.5 & 12 & 12.5 & 13 & 13.5 & 14 & 14.5 & 15\end{array}$ $\begin{array}{lllllllllllllllllllllllllllllllll}0 & 0.5 & 1 & 1.5 & 2 & 2.5 & 3 & 3.5 & 4 & 4.5 & 5 & 5.5 & 6 & 6.5 & \mathbf{7} & 7.5 & 8 & 8.5 & \mathbf{9} & 9.5 & 10 & 10.5 & 11 & 11.5 & 12 & 12.5 & 13 & 13.5 & 14 & 14.5 & 15\end{array}$ $\begin{array}{lllllllllllllllllllllllllllllll}0 & 0.5 & 1 & 1.5 & 2 & 2.5 & 3 & 3.5 & 4 & 4.5 & 5 & 5.5 & 6 & 6.5 & 7 & 7.5 & 8 & 8.5 & 9 & 9.5 & 10 & 10.5 & 11 & 11.5 & 12 & 12.5 & 13 & 13.5 & 14 & 14.5 & 15\end{array}$ $\begin{array}{lllllllllllllllllllllllllllllll}0 & 0.5 & 1 & 1.5 & 2 & 2.5 & 3 & 3.5 & 4 & 4.5 & 5 & 5.5 & 6 & 6.5 & 7 & 7.5 & 8 & 8.5 & 9 & 9.5 & 10 & 10.5 & 11 & 11.5 & 12 & 12.5 & 13 & 13.5 & 14 & 14.5 & 15\end{array}$ $\begin{array}{lllllllllllllllllllllllllllllll}0 & 0.5 & 1 & 1.5 & 2 & 2.5 & 3 & 3.5 & 4 & 4.5 & 5 & 5.5 & 6 & 6.5 & 7 & 7.5 & 8 & 8.5 & 9 & 9.5 & 10 & 10.5 & 11 & 11.5 & 12 & 12.5 & 13 & 13.5 & 14 & 14.5 & 15\end{array}$ $\begin{array}{lllllllllllllllllllllllllllllll}0 & 0.5 & 1 & 1.5 & 2 & \mathbf{2 . 5} & 3 & 3.5 & 4 & 4.5 & 5 & 5.5 & 6 & 6.5 & 7 & 7.5 & 8 & 8.5 & 9 & 9.5 & \mathbf{1 0} & 10.5 & 11 & 11.5 & 12 & 12.5 & 13 & 13.5 & 14 & 14.5 & 15\end{array}$ $\begin{array}{lllllllllllllllllllllllllllllll}0 & 0.5 & 1 & 1.5 & 2 & 2.5 & 3 & 3.5 & 4 & 4.5 & 5 & 5.5 & 6 & 6.5 & 7 & 7.5 & 8 & 8.5 & 9 & 9.5 & 10 & 10.5 & 11 & 11.5 & 12 & 12.5 & 13 & 13.5 & 14 & 14.5 & 15\end{array}$

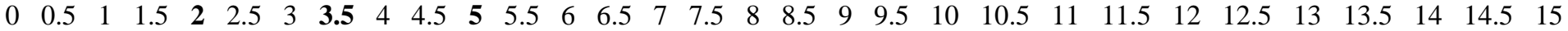

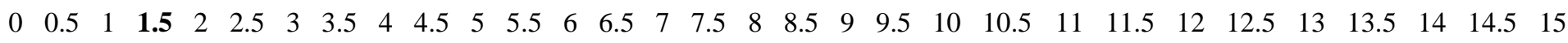

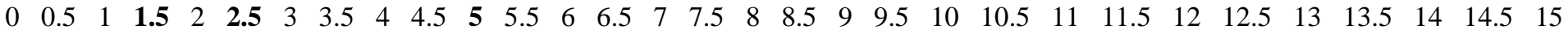
$\begin{array}{llllllllllllllllllllllllllllllll}0 & 0.5 & 1 & 1.5 & 2 & 2.5 & 3 & 3.5 & 4 & 4.5 & 5 & 5.5 & 6 & 6.5 & 7 & 7.5 & 8 & 8.5 & 9 & 9.5 & 10 & 10.5 & 11 & 11.5 & 12 & 12.5 & 13 & 13.5 & 14 & 14.5 & 15\end{array}$

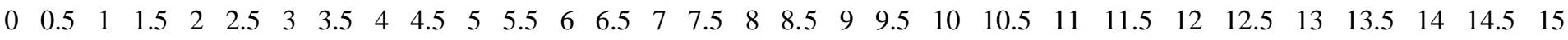




\section{AMPLITUDE}

Impact

$\begin{array}{lllllllllllllllllllllllllllllll}0 & 0.5 & 1 & 1.5 & 2 & 2.5 & 3 & \mathbf{3 . 5} & 4 & 4.5 & 5 & \mathbf{5 . 5} & 6 & 6.5 & 7 & 7.5 & 8 & 8.5 & 9 & 9.5 & 10 & 10.5 & 11 & 11.5 & 12 & 12.5 & 13 & 13.5 & 14 & 14.5 & 15\end{array}$

Blendedness

$\begin{array}{lllllllllllllllllllllllllllllll}0 & 0.5 & 1 & 1.5 & 2 & 2.5 & 3 & 3.5 & 4 & 4.5 & 5 & 5.5 & 6 & 6.5 & 7 & 7.5 & 8 & 8.5 & 9 & 9.5 & \mathbf{1 0} & 10.5 & 11 & 11.5 & 12 & 12.5 & 13 & 13.5 & 14 & 14.5 & 15\end{array}$

Fullness

$\begin{array}{llllllllllllllllllllllllllllllll}0 & 0.5 & 1 & 1.5 & 2 & 2.5 & \mathbf{3} & 3.5 & 4 & 4.5 & 5 & 5.5 & 6 & 6.5 & 7 & 7.5 & \mathbf{8} & 8.5 & 9 & 9.5 & 10 & 10.5 & 11 & 11.5 & 12 & 12.5 & 13 & 13.5 & 14 & 14.5 & 15\end{array}$

Longevity

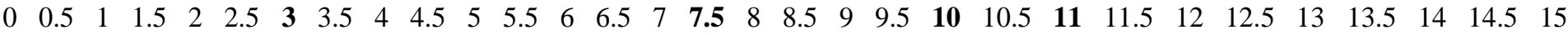

Overall Amplitude

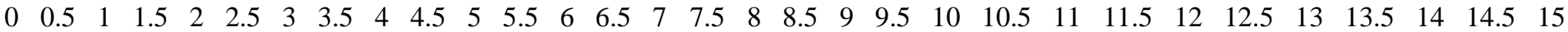




\section{Appendix B - SAS® Codes}

\section{SAS® Code for Analyzing Descriptive Test Data}

option nodate pageno $=1$;

data data name;

input Sample\$ Panelist\$ Rep\$ atr1 atr2 atr3 atr4 atr5 atr6 atr7 atr8 atr9 atr10 atr11 atr12 atr13 atr14 atr15 atr16 atr17 atr18 atr19 atr20 atr21 atr22 atr23 atr24 atr25 atr26 atr27 atr28 atr29 atr30 atr31 atr32 atr33 atr34 atr35;

cards;

(input raw data here)

;

ods rtf;

proc glimmix data=(data name);

class sample rep panelist;

model atr\# = sample/ddfm=sat;

random rep panelist;

lsmeans sample/ pdiff lines;

run;

ods rtf close; quit;

ODS Listing;

ODS RTF CLOSE;

\section{Notes}

1. The number of "atr\#" input variables corresponds to the number of attributes on the respective ballots (i.e. 22 attributes for raw black walnuts and 25 attributes for black walnut cookies).

2. The PROC GLIMMIX procedure is repeated for each attribute resulting in 35 individual codes for the porridge attributes.

3. "atr\#" is replaced by "atr1", "atr2", ..., "atrXX" for each of the attributes. 


\section{SAS $®$ Code for Analyzing Viscosity}

option nodate pageno $=1$;

data data name;

input sample\$ rep\$ Viscosity;

cards;

(input raw data here)

;

ods rtf;

proc means; var Viscosity; run;

proc glimmix;

class sample rep;

model Viscosity $=$ sample $/ \mathrm{ddfm}=$ sat;

random rep;

lsmeans sample/ pdiff lines;

run;

ods rtf close; quit;

ODS Listing;

ODS RTF CLOSE;

Notes

The PROC GLIMMIX procedure is repeated for each study 